\title{
Tumor-Associated Macrophages-Implications for Molecular Oncology and Imaging
}

\author{
Melanie A. Kimm ${ }^{1}{ }^{\circledR}$, Christopher Klenk ${ }^{1}$, Marianna Alunni-Fabbroni ${ }^{1}$, Sophia Kästle ${ }^{1}$, Matthias Stechele ${ }^{1}$, \\ Jens Ricke ${ }^{1}$, Michel Eisenblätter ${ }^{2}$ and Moritz Wildgruber ${ }^{1, *}$ \\ 1 Department of Radiology, University Hospital, LMU Munich, 81377 Munich, Germany; \\ melanie.kimm@med.uni-muenchen.de (M.A.K.); christopher.klenk@med.uni-muenchen.de (C.K.); \\ Marianna.Alunni@med.uni-muennchen.de (M.A.-F.); sophia.kaestle@med.uni-muenchen.de (S.K.); \\ matthias.stechele@med.uni-muenchen.de (M.S.); jens.ricke@med.uni-muenchen.de (J.R.) \\ 2 Department of Diagnostic and Interventional Radiology, Freiburg University Hospital, 79106 Freiburg, \\ Germany; michel.eisenblaetter@uniklinik-freiburg.de \\ * Correspondence: moritz.wildgruber@med.uni-muenchen.de; Tel.: +49-0-89-4400-76640
}

Citation: Kimm, M.A.; Klenk, C.; Alunni-Fabbroni, M.; Kästle, S.; Stechele, M.; Ricke, J.; Eisenblätter, M.; Wildgruber, M. Tumor-Associated Macrophages-Implications for Molecular Oncology and Imaging. Biomedicines 2021, 9, 374. https:// doi.org/10.3390/biomedicines9040374

Academic Editor: Alexei Gratchev

Received: 3 March 2021

Accepted: 31 March 2021

Published: 2 April 2021

Publisher's Note: MDPI stays neutral with regard to jurisdictional claims in published maps and institutional affiliations.

Copyright: (c) 2021 by the authors. Licensee MDPI, Basel, Switzerland. This article is an open access article distributed under the terms and conditions of the Creative Commons Attribution (CC BY) license (https:/ / creativecommons.org/licenses/by/ $4.0 /)$.

\begin{abstract}
Tumor-associated macrophages (TAMs) represent the largest group of leukocytes within the tumor microenvironment (TME) of solid tumors and orchestrate the composition of anti- as well as pro-tumorigenic factors. This makes TAMs an excellent target for novel cancer therapies. The plasticity of TAMs resulting in varying membrane receptors and expression of intracellular proteins allow the specific characterization of different subsets of TAMs. Those markers similarly allow tracking of TAMs by different means of molecular imaging. This review aims to provides an overview of the origin of tumor-associated macrophages, their polarization in different subtypes, and how characteristic markers of the subtypes can be used as targets for molecular imaging and theranostic approaches.
\end{abstract}

Keywords: tumor microenvironment; monocytes; macrophages; molecular imaging; polarization

\section{Formation of the Tumor Microenvironment}

The formation of a pro-tumorigenic microenvironment is crucial for the survival of cancer cells at the primary and distant sites. The interplay between tumor cells, stroma, components of the extracellular matrix (including chemokines, cytokines, and hormones) and the immune system decides about the faith of primary tumors and metastases. Each stage of tumor development is characterized by its metabolic and cellular fingerprint influencing homeostasis between tumor progression and destruction.

The transformation of a normal cell into a tumor cell follows the accumulation of mutations in cancer genes. These mutations can be caused by errors during DNA replication or due to substantial DNA damage [1]. The accumulation of mutations leads to alterations of the cell and transforms it into a cancer cell. However, one cancer cell alone does not form a tumor. During evolution, the organism has developed several protection mechanisms for the elimination of cells that do not behave normally [2]. Thus, in order to expand, the cancer cells must escape this surveillance and build up their own tumor-friendly microenvironment [3].

Compared to a normal tissue environment, TME differs in architecture, nutritional state, $\mathrm{pH}$ value, oxygen levels, and the composition of the extracellular matrix. Remodeling of the extracellular matrix by cancer-associated fibroblasts (CAF) and stromal expansion results in a stiff environment with increased interstitial pressure [4]. This physical force together with biochemical signals facilitates epithelial-mesenchymal transition (EMT) as gene expression can be modulated [5-7]. Another hallmark of the TME is the creation of its own immune microenvironment, which encompasses T and B lymphocytes, NK cells, monocytes and myeloid-derived suppressor cells (MDSCs), mast cells, granulocytes, 
dendritic cells (DC), neutrophils, CAF, adipocytes, vascular endothelial cells, pericytes, and tumor-associated macrophages (TAMs) [8]. Furthermore, the metabolic reprogramming of the tumor environment (lactate and lipid metabolism, reactive oxygen species (ROS)) and the creation of specific conditions such as hypoxia is an essential aspect [9-11]. Tumorderived secreted factors, chemokines, cytokines, and exosomes complete the TME [12-16]. During tumor growth, the TME constantly develops further and at any time point encompasses a heterogeneous landscape $[17,18]$. This heterogeneity hampers the effect of highly specific therapies. Thus, revealing the patient-specific microenvironment at the primary tumor level and at the distant metastatic site will allow for a better prediction of therapy response and potentially enable consecutive tailoring of therapy regimen [18-20]. The TME in this context provides targets for novel therapies aiming at normalization of the microenvironment to facilitate successful treatment of cancer patients [21-23]. In general, a healthy environment inhibits tumorigenesis, and thus, converting specific TME characteristics back to non-tumorigenic environment could be the key to improve cancer therapy.

\section{Myeloid Cells: Monocytes and M-MDSCs}

At every stage of disease progression, the tumor cells exert influence on the associated microenvironment, and in turn, the TME influences the tumor cells.

Chronic inflammation is an accepted hallmark of cancer, and inflammatory factors can both promote and eliminate tumor cells $[24,25]$. The current understanding of the complex role of inflammatory cells in the TME and their contribution to tumorigenesis is the following: at early stages of tumor development, cytotoxic immune cells (CD8 ${ }^{+} \mathrm{T}$ cells and NK cells) recognize and eliminate immunogenic tumor cells as a physiological mechanism [26,27]. However, remaining less immunogenic tumor cells become invisible to the immune cells and are thus able to expand. In addition, by downregulating tumor antigens and NK activation factors on the surface of tumor cells, they are able to escape their recognition and elimination by cytotoxic T cells and NK cells $[2,28,29]$. Moreover, tumor-derived, immunosuppressive signaling molecules such as IL-10, TGF- $\beta$, VEGF, and prostaglandin E2, as well as the expression of checkpoint molecules such as PD-L1 and CTLA-4, pave the way for the recruitment of MDSCs, TAMs, and $\mathrm{T}_{\text {reg }}$, orchestrated by tumor cell-derived chemokines such as CCL2, CSF1, CCL5, CCL22, CXCL5, CXCL8, and CXCL12 [15,30-37].

Monocytes develop from myeloid progenitor cells in the bone marrow, enter the circulation and migrate into various tissues where they differentiate to macrophages and DCs [38,39]. As monocytes, macrophages and DCs are capable of regulating T cell responses, therefore bridging innate and adaptive immunity [40]. Monocytes comprise a heterogenous group and were originally divided into a classical $\left(\mathrm{CD} 16^{-} \mathrm{CD} 14^{+}\right)$, a nonclassical $\left(\mathrm{CD} 16^{+} \mathrm{CD} 14^{\text {low }}\right)$, and an intermediate $\left(\mathrm{CD} 16^{+} \mathrm{CD} 14^{+}\right)$subtype $[41,42]$. They are characterized by high functional plasticity, including the production of cytokines, clearance of pathogens, and antigen presentation. It has been shown that classical monocytes convert into non-classical over time [43,44]. How long each of the subtypes remains within the circulation and their relationship among each other is still under investigation. Only recently, the classification of monocytes was replaced in favor of their function (inflammatory, patrolling, and immunosuppressive monocytes) rather than classifying solely with respect to cell surface profiles [42,45-48]. The nomenclature of monocyte subsets is still not harmonized, and both classification types can be found. Inflammatory monocytes represent the classical subtype characterized by the expression of the CCR2 chemokine receptor, necessary to egress from the bone marrow and enter the blood circulation. At steady-state, inflammatory monocytes invade tissues and fill up the pool of tissue-resident monocyte-derived cells, finally differentiating into macrophages and dendritic cells. In addition, inflammatory monocytes are able to remain in their monocyte-like state and reside as local monocytes within the tissue [49]. Patrolling monocytes are the guardians of the vasculature and equal the non-classical monocyte subtype [50]. They are more differentiated than classical monocytes and characterized by the expression of CX3CR1. 
They survey the endothelium by constantly crawling along the lumen of the vasculature in an LFA/ICAM-dependent matter [46]. Studies in mice have shown that patrolling monocytes might not only descend from inflammatory monocytes but may also originate directly from a monocyte progenitor cell [51,52]. The intermediate monocyte subset (which is absent in mice) is hypothesized to be monocytes in transition [43], which could explain why there is no functional nomenclature for this subtype so far. At steady-state, they exhibit phagocytic and anti-inflammatory functions as well as high levels of intracellular IL-1 $\beta$ and TNF- $\alpha$ (pro-inflammatory mediators). The last subtype of functional monocytes is the immunosuppressive one including the monocytic myeloid-derived suppressor cells (M-MDSCs) which are mainly considered separately from the other monocyte subsets. They are pathologically activated myeloid cells and involved in facilitating tumor escape [53]. Their surface marker profile $\mathrm{CD} 11 \mathrm{~b}^{+} \mathrm{CD} 14^{+} \mathrm{CD} 15^{-} \mathrm{HLA}-\mathrm{DR} \mathrm{low}^{\text {low }}$ allows the distinction between M-MDSCs and inflammatory and patrolling monocytes. Yet, under non-pathological conditions, the immature myeloid cells differentiate into monocytes. But under pathological conditions (stress, inflammation, and cancer) immature myeloid cells respond to emergency signals from the pathological site, preventing them from full differentiation and turning them into M-MDSCs [54]. Compared to monocytes, M-MDSCs exhibit differences in their gene expression and biochemical profile, which relates to their different functional activity. For separating monocytes and MDSC populations, HLA-DR is the most common marker as monocytes are positive for HLA-DR, whereas MDSCs are either low expressors or negative [55]. The immunosuppressive activity of M-MDSC is attributed to the secretion of arginase 1 (ARG1), inducible nitric oxide synthase (iNOS), as well as the production of ROS and nitric oxide (NO). They further express immune checkpoint molecules such as PD-L1 and CTLA-4 [55,56]. M-MDSCs specifically inhibit effector T cells within the TME in an antigen-specific and non-specific manner [56,57]. It is believed that M-MDSCs have evolved as protection from uncontrolled immune response associated with unresolved inflammation and M-MDSCs are a common feature of sepsisinduced immunoparalysis $[58,59]$. As a result, M-MDSCs in sepsis lead to the exhaustion of lymphocytes, which in turn stop the production of cytokines such as IFN- $\gamma$ and IL-12. This mechanism also supports tumor cell survival, and thus, therapeutic targeting of M-MDSCs within the TME is a promissing tool to convert the tumor microenvironment into a normal tissue microenvironment and thus control cancer growth.

\section{Recruitment and Polarization of M-MDSCs and Macrophages}

All tumors exhibit a complex landscape of myeloid cells which are, among other cells, responsible for therapeutic responses [60]. Tumor cells and tumor-associated fibroblasts drive cancer-associated myelopoiesis by secreting soluble factors leading to the recruitment and expansion of myeloid cells from the bone marrow. These signals not only increase the myeloid output from the bone marrow but also modify the hematopoietic niche and alter myelopoiesis [61]. Among them are chemokines such as CCL2, colony-stimulating factors (G-CSF, M-CSF), stem cell factors, VEGF, cytokines such as IL-3 and IL-6, and regulatory proteins such as S100A8 and S100A9 [62-68]. In addition, these stimuli prevent immature myeloid cells from differentiating into monocytes leading to the formation of M-MDSCs. The pathological activation of M-MDSC already starts in the bone marrow mainly by inflammatory cytokines, which also attract M-MDSCs to the tumor site. Here, M-MDSCs either differentiate into tumor-associated macrophages (TAMs) or remain as M-MDSC population in the TME, where they play an important role in tumor progression as they directly act on the function of other immune cells. Per definition, M-MDSCs develop upon pathological conditions and exhibit immunosuppressive functions. Depending on the growth factors and inflammatory mediators in the environment, MDSCs differentiate in M1or M2-like cells (according to the classification of T helper cells and macrophages), which can be identified by specific molecular markers [69,70] and functions (Figure 1). M1-like M-MDSCs have been shown to suppress tumor growth by increasing the amounts of free radicals (NO), death ligands (TNF- $\alpha$ ), and immune cell-stimulating cytokine IL-12 [71,72]. 
In tumor tissue, mainly pro-tumorigenic, M2-like M-MDSCs are the dominant type, which inhibit tumor cell killing mediated by cytotoxic $\mathrm{T}$ lymphocytes primarily through IL-10, TGF- $\beta$, and ARG1 [73]. Furthermore, several studies have shown the importance of toll-like receptors (TLR) and IFN $\gamma$ for M1-like M-MDSCs and IL-4 and IL-13 for the M2-like type (Table 1). So far, several compounds have been identified that are able to shift M2 MMDSCs to M1 M-MDSCs, opening a new field to treat cancer [74]. Downstream pathways of potential targets in the reprograming process need to be investigated, but as MDSCs are crucial players in regulating the immune response in tumors. Understanding their molecular signature and behavior may be a game-changer in the treatment of a variety of diseases. Next to their own function as M1 or M2 M-MDSCs, studies have shown that within tumor tissue, they are able to develop further into TAMs. Thus, they comprise a class of monocytes which, in addition to classical monocytes (inflammatory and patrolling), can give rise to macrophages within tumor tissue [75].

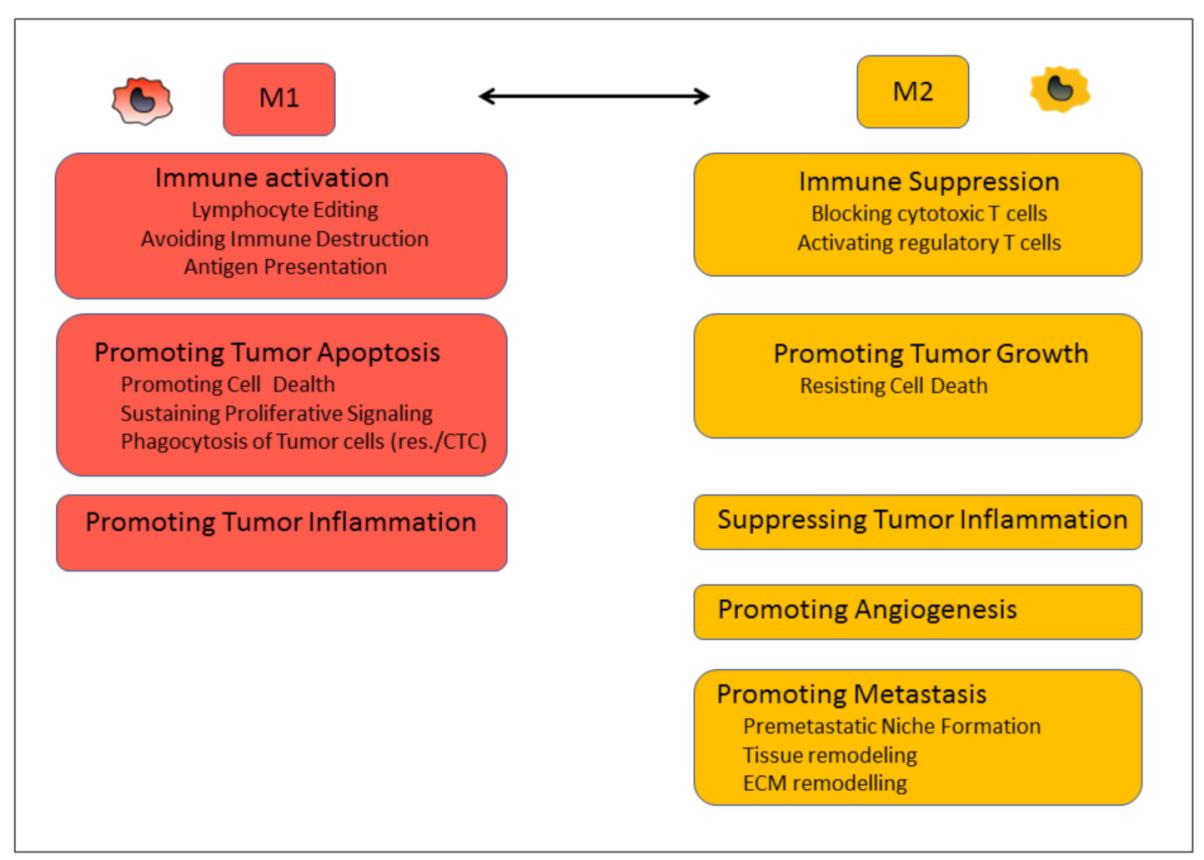

Figure 1. Functional hallmarks of M1 and M2 TAMs.

This finding illustrates why macrophages also display such a heterogeneous group. Furthermore, factors in the tissue environment determine their function. Macrophages are terminally differentiated myeloid cells that can be found in all tissues. Some of them derive from circulating monocytes, some of them from tissue-resident monocytes, and some of them from tissue-resident macrophages [76]. The ontogeny of TAMs is still under investigation, but analogous to other immune cells, two subtypes of TAMs, M1 (anti-tumorigenic) and M2 (pro-tumorigenic) phenotypes are described [77,78] (Figure 1).

To make it even more complicated, there is more than one pool where TAMs are recruited from. The study from Fogg et al. [79] identified a precursor for monocytes, macrophages, and dendritic cells and emphasized the potential that monocytes can reconstitute tissue macrophages under certain conditions. A monocyte-restricted precursor was found in the bone marrow, which derived from a common progenitor and is distinguishable to a common dendritic precursor by differences in c-Kit expression and loss of the CD135 surface marker [80]. Even though several studies showed that circulating monocytes can give rise to tissue-resident macrophages, it is not yet fully clarified to what extent they do differentiate into macrophages. Over time, more and more details about tissue-resident macrophages have been identified and finally lead to today's view on how macrophages derive. For example, macrophages in the brain (microglia) derive from the yolk sac. Tissue-resident macrophages from other organs such as the gut, heart, lung (alve- 
olar macrophages), spleen, bone (osteoclasts), skin (Langerhans cells), and liver (Kupffer cells) comprise cells of multiple developmental origins, all of them being established prior to birth and able to maintain themselves independently from blood monocytes during adulthood [81,82]. The number of tissue-resident macrophages seems to play a crucial physiological role, and changes within the population correlate with early aging [83]. A certain percentage of tissue-resident macrophages is continuously updated from bloodderived myeloid cells but differs from tissue to tissue and changes upon disease [84]. As an example, microglia strictly repopulate from yolk sac-derived progenitor cells, whereas heart-resident macrophages are replaced by blood-derived monocytes [85,86]. Upon injury, Kupffer cells in the liver can derive from liver-resident macrophages, monocyte-derived macrophages, or peritoneal macrophages [87]. The latest results from single-cell RNA sequencing of human liver macrophages revealed the existence of two distinct populations next to each other, one of which is anti-inflammatory, the other pro-inflammatory [88]. The ontogeny of these two populations still needs to be elucidated, and it could very well be that the pro-inflammatory subtype derives from circulating monocytes. At steady-state, Kupffer cells renew independently from bone marrow-derived progenitors, but recent studies showed that monocyte-derived macrophages might be an alternative source for Kupffer cells under certain conditions. The activation of chemokine ligands (e.g., CCL2, CXCL1, and CXCL10) on Kupffer or hepatic stellate cells seems to be the main driver for monocyte infiltration into the liver following injury or infection [89-92]. The least wellstudied population of liver-resident macrophages are the peritoneal macrophages. Wang et al. were able to identify $\mathrm{F} 4 / 80^{\text {hi }} \mathrm{GATA} 6^{+} \mathrm{CD} 11 \mathrm{~b}^{+}$mature macrophages to accumulate in the liver following thermal injury [93]. They further reported that none of the bone marrow-derived monocyte subpopulations infiltrated the site of injury. When it comes to injury, spleen-derived monocytes also enter the game [94]. During the development of liver fibrosis, splenic macrophages fuel the hepatic inflammation by secreting pro-inflammatory mediators into the portal vein $[95,96]$. Hematopoietic stem and progenitor cells (HSPCs) found in the spleen were phenotypically and functionally analogous to HSPCs found in the bone marrow and they also gave rise to monocytes that were able to enter the tumor $[97,98]$. Studies on the influence of splenectomy revealed a role of the spleen in immune surveillance and protection from tumor development and metastasis [99,100].

Summing it up, macrophages in tumor tissue most likely present a heterogeneous population of cells derived from monocytes from bone marrow, spleen, and blood as well as tissue-resident macrophages. The fate of TAMs (M1 or M2 subtype) might be pre-determined by the origin of the cell and by tumor-derived mediators present in the blood and in the tumor microenvironment (Figure 2).

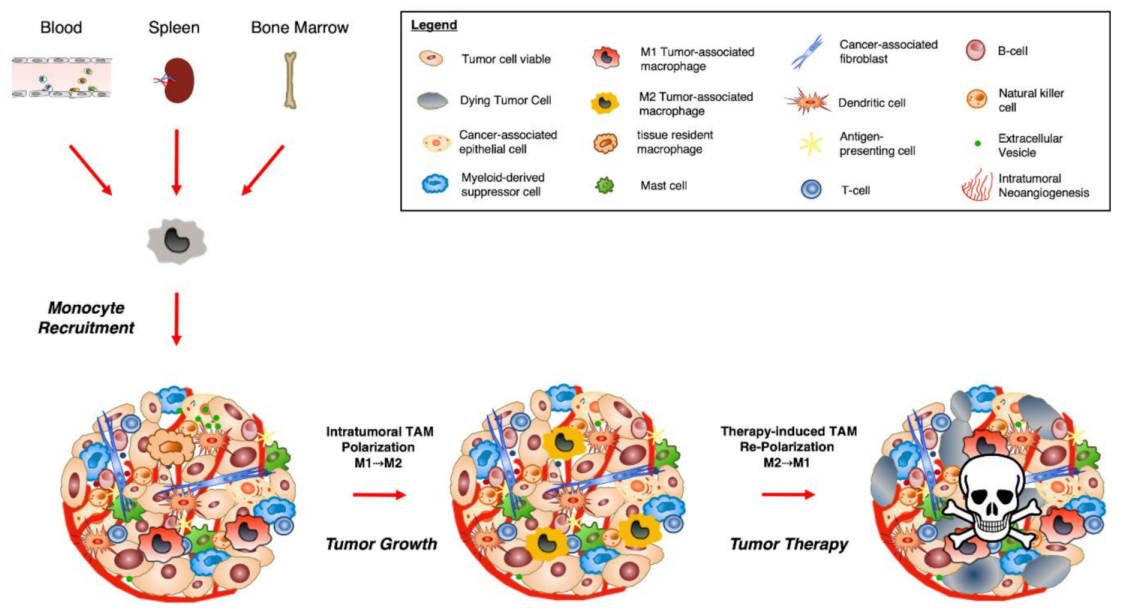

Figure 2. Monocyte recruitment and TAM polarization during tumor development and therapy. Monocytes from different compartments (bone marrow, blood, spleen) are directed to the tumor microenvironment (TME) via secreted factors and exosomes. Here, they differentiate into TAMs of different subtypes (M1/M2). Therapies leading to the repolarization of M2 TAMs into M1 TAMs or monocytes are promising strategies for tumor destruction. 


\section{TAM Targeting}

Once macrophages are located in the TME, their function depends on the subtype: pro-inflammatory M1-like TAMs show a tumor-suppressive behavior, promoting a positive therapeutic response and improved patient survival. In contrast, M2-like TAMs promote primary tumor survival, metastasis, and correlate with a worse therapeutic outcome. As M2-like TAMs are the predominant population of macrophages within the tumor tissue, TAMs and M2-activated macrophages (in tumor tissue) are often used synonymously in the literature. Even though M1- and M2-like TAMs harbor distinct profiles, TAMs are regarded as remarkable plastic, and the subtypes can pass over from one to the other [101]. Initially, macrophages were classified according to their activation agent: LPS and IFN- $\gamma$ activated M1 type and IL-4 and IL-10 activated M2 type [81]. Nowadays, macrophage grouping is primarily related to the function of the macrophage following the monocyte classification. Even though M1 and M2 TAMs show different genetic profiles, the favored idea is that TAMs differ in their function rather than their phenotype [101]. This idea is supported by studies showing that various stimuli lead to an alteration in the TAM phenotype allowing a switch from M1 into M2 and vice versa [102,103]. In particular, the repolarization of TAMs into the pro-inflammatory M1-like type is the subject of numerous investigations. The microenvironment is the most crucial factor for TAM polarization [104], which makes it even harder to explain why M1- and M2-like TAMs together with intermediate forms, expressing genes from both types, do exist next to each other [105]. Recently, subtypes of M2-like TAMs have been identified and classified as M2a, M2b, M2c, and others [106,107]. The induction of one or the other subtype is a result of different stimuli in the environment. M2a macrophages express high levels of mannose receptors, M2b macrophages are known as regulatory ones, and M2c macrophages are induced by IL-10 [108-110]. The proper characterization of these subtypes is important in regard to tumor therapy as specific targeting reduces side effects and improves the reformation of the microenvironment toward a tumor-suppressive one.

Next to the polarization of TAMs by chemokines and cytokines, the interaction with tumor-derived extracellular vesicles (EVs) plays an important role in TAM determination. In addition, several micro RNAs (miRNA or MiR) have been described to be involved in the differentiation of myeloid cells into macrophages and also in the polarization of TAMs [111-113]. M2-like TAMs overexpressing miRNA-155 repolarize to M1 [114], and inhibition of miRNA-155 impairs M1 functions. M1 polarization is also assisted by miRNA127 and miRNA-125b $[115,116]$ (Table 1). EVs and exosomes carrying RNAs and proteins from M1-like TAMs are capable of switching M2-like TAMs to M1 and potentiate an antitumor effect. As exosomes can act as a carrier to deliver therapeutics into the tumor [117], several efforts have been made to diminish TAMs directly or to repolarize them by using EVs as a vehicle. Another strategy is to block monocyte infiltration in tumor tissue, cutting down one resource of TAMs. CCR2 expressing monocytes are driving tumor progression, and therefore, inhibiting the CCL2-CCR2 axis could stop tumor expansion [118]. Several clinical trials with CCR2 blockers are ongoing [119]. Targeting CXCR4 has also shown promising results in preclinical models [120]. The direct depletion of TAMs is another strategy to support anti-tumor therapies. Bisphosphonates such as zoledronate, clodronate, and trabectedin have been shown to reduce TAM survival by inducting cell cycle arrest [121]. However, depletion of TAMs might have the consequence that all myeloid cells in the tumor are getting destroyed, and the loss of pro-inflammatory macrophages could cause side effects and even fire tumor progression as macrophages are needed for efficient immunotherapy [122]. Thus, repolarization of M2-like TAMs is assumed to be the better strategy. The most effective way seems to include targeting both the tumor cell (e.g., CD47/SIRP $\alpha$ ) and TAMs (e.g., TLR antagonist, PI3K $\gamma$ inhibitor, CD40 agonist, and HDAC inhibitors) [123,124]. Loading drugs into macrophages can be accomplished using nanoparticles as carriers [125]. Silica and gold nanoparticles, liposomes, and other polymers are currently under investigation. Very recently, live cells are executed to deliver drugs to tumor cells. Monocytes/macrophages are ideal candidates as they can ingest relatively 
large amounts of drugs, and they are easily recruited to tumors [126,127]. Preclinical and clinical studies targeting TAMs are listed in Table 2.

Table 1. Common macrophage markers.

\begin{tabular}{ccc}
\hline M1 & & M2 \\
\hline CD80, CD86 [128,129] & CD surface receptor & $\begin{array}{c}\text { CD163, CD206, CD200R } \\
{[128,130,131]}\end{array}$ \\
\hline $\begin{array}{c}\text { CXCL8, CXCL9, CXCL10, } \\
\text { CCL2, CCL3, CCL5 [132] }\end{array}$ & Chemokines & CXCL12, CCL2,3,4,5,18,20 \\
{$[133,134]$}
\end{tabular}

Table 2. TAM targeting therapies in preclinical or clinical studies.

\begin{tabular}{ccc}
\hline TAM Recruitment & TAM Depletion & TAM Reprogramming \\
\hline CCCR2-CCL2 inhibition [183-185] & Trabectedin [186,187] & Class IIa HDAC inhibitors [188,189] \\
CXCR4-CXCL12 inhibition [190] & Biphosphonates [121,191] & CD40 agonists [192,193] \\
& PI3K $\gamma$ inhibitors [196] \\
& & SIRP $\alpha$ inhibitors [197,198] \\
& & STAB1 inhibitors [199] \\
& & Checkpoint inhibitors [200] \\
& TLRs agonists [201] \\
\hline
\end{tabular}

\section{TAM Tracking and Imaging}

Imaging of TAMs and tracking their fate over time is not only necessary to understand the dynamic role of mononuclear phagocytes within the TME but also to monitor therapies that are targeting TAMs specifically. As TAMs are the most abundant cells within the TME, imaging can be performed with higher signal-to-noise compared to less abundant immune cells in the TME. Molecular sensors can target TAMs in principle by three different means: (i) TAM-specific antibodies (such as CD68 or CD206) coupled to signal moieties of a different kind (magnetic resonance agents, radionuclides, or nanoparticles); (ii) the phagocytic or metabolic capacity can be used to introduce signal moieties into TAMs themselves; and (iii) reporter gene imaging of TAMs.

Targeting subset-specific receptors expressed by different TAMs may become suitable to assess the dominating polarization type abundant in the TME. Targeting the folate (M1) and the mannose receptor (M2) using dedicated near infrared (NIR) sensors or radiotracers 
has been explored primarily beyond the tumor field but can potentially be applied to assess the status and amplitude of immune activation in vivo [203-205]. Folate-conjugated fluorescein isothiocyanate (folate-FITC) was shown to capture tumor-infiltrating immune cells in a mouse model of head and neck squamous carcinoma [206]. Recently, folateconjugated nanobubbles were evaluated for both TAM targeting and reeducation [207]. A nanobody-based targeting CD206 has been shown to selectively capture pro-angiogenic TAMs residing in hypoxic areas of the TME [208]. Using nanobodies, which are singledomain antigen-binding fragments derived from Camelidae heavy-chain antibodies, has the benefit of improved delivery and accumulation within the tumor, which is a hurdle of many large-molecule contrast agents and sensors. Antibodies, due to their size, frequently suffer from a poor penetration of solid tumors and a high Fc-mediated unspecific binding, thereby causing a poor signal-to-noise of the TME on in vivo imaging. Nanobodies instead are chemically stable, soluble, and exert a high affinity and increased tissue penetration, making them favorable for targeting the TME [209]. Coupling nanobodies with signal-giving moieties may thus overcome the current limitations of antibody-based molecular imaging, frequently suffering from an insufficient tumor-to-noise ratio. Labeling nanobodies targeting CD206 with ${ }^{99 \mathrm{~m}} \mathrm{Tc}$ has been shown to successfully image specific TAM subpopulations in vivo [208].

The simplest way to image macrophages in vivo is using their high phagocytic activity to take up nanoparticles. Labeling nanoparticles with various PET tracers for whole-body imaging can be either achieved through incorporating suitable isotopes or by chelation of such isotopes with the nanoparticle [210]. Locke et al. developed a mannosylated liposome loaded with ${ }^{64} \mathrm{Cu}$ that accumulated in TAMs in a mouse model of pulmonary adenocarcinoma and was able to quantify the tumoral TAM load by PET imaging [211]. Of note, such a nanoparticle delivery system can not only be used for molecular imaging of TAM content and activity but can similarly be combined with delivering therapeutic agents to the TME in a theranostic approach [212-214]. As a general limitation, one has to mention that rarely are these approaches $100 \%$ specific, neither for TAMs nor a specific subset. For example, the mannose receptor is not exclusively expressed by TAMs with M2 polarization but also on resident macrophages and other phagocytes. As TAMs were identified as the main containers for high-density lipoproteins (HDLs) with the TME, using the HDLs as delivery cargo for nanoparticle-based tracers may increase the specificity of TAM imaging. Selective targeting of TAMs was observed in an orthotopic murine breast cancer model by using ${ }^{89} \mathrm{Zr}$-reconstituted HDL as a PET tracer [215]. Besides addressing the mere presence of TAMs, tracking their biological activity may be even more meaningful, especially when monitoring therapeutic effects of TME specific therapies. S100A8/ A9 has been identified as a promising marker for monocyte activation within the inflammatory TME [216]. Fluorescence imaging of the heterodimer protein S100A8/ A9 has been shown to report specific features of malignancy in a murine breast cancer model [217,218] (Figure 3). Using a similar model, Eisenblätter et al. showed that S100A8/A9 can be used as an imaging biomarker for pre-metastatic tissue priming. S100A8/A9 expression detected by SPECT revealed myeloid-derived suppressor cell abundance in pre-metastatic lung tissue before the onset of actual metastasis. S100A8/A9 signal correlated with subsequent tumor burden of lung metastasis and selective CCL2 blockade was able to modulate TAM activity within the TME and influence subsequent metastatic growth [219]. S100A9 NIR imaging further allowed to capture therapy-mediated changes of the inflammatory tumor microenvironment following Doxorubicin/Bevacizumab treatment or murine breast cancer xenografts [217]. 


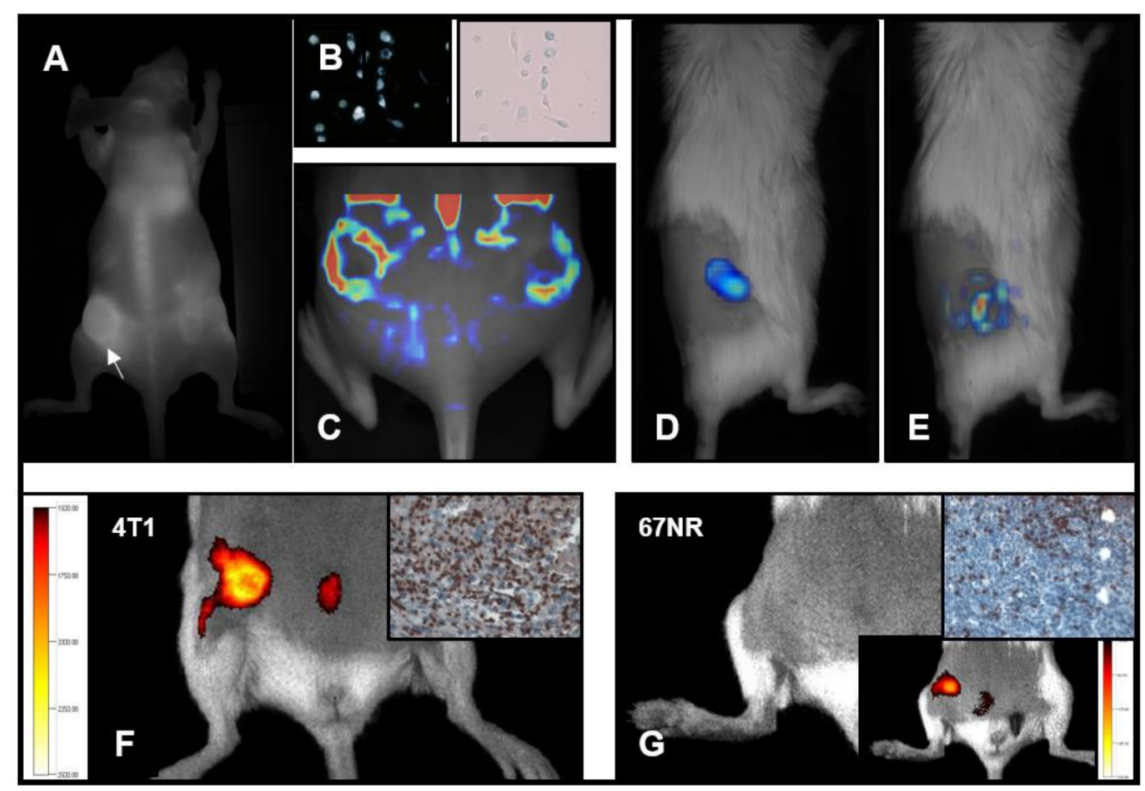

Figure 3. TAM tracking using optical imaging. (A-C) DiR-labeled macrophages (B), directly tracked $48 \mathrm{~h}$ after intravenous application using FRI (A) and FMT (C). The signal represents local macrophage accumulation in 4T1 tumors, implanted in the flanks of mice (adopted with permission of [220]). (D-G) Homogeneous tracer distribution in tumors after injection of control IgG-Cy7 (D) and TAM-targeted S100A9-Cy5.5, which accumulates in the tumor periphery (E). The TAM activity reflects the tumor malignancy: S100A9-Cy5.5 gives a stronger signal in highly malignant $4 \mathrm{~T} 1$ tumors (F) than in slowgrowing, less aggressive 67NR tumors (G). Inserts (upper right corner) show corresponding immunohistochemistry of S100A9 ${ }^{+}$TAMs (adopted with permission of [218]).

The most established way of tracking macrophages is labeling with small or ultrasmall superparamagnetic iron oxide nanoparticles (SPIO/USPIO). Those particles are preferentially taken up by monocytes/macrophages via phagocytosis and induce a strong signal decay on T2* weighted magnetic resonance imaging [221,222]. Tracking of TAM accumulation within the TME during tumor growth has been initially reported by Shih et al. [223]. It is important to note that in mice and humans, phagocytosis activity may differ between distinct monocyte/macrophage subsets [221,224]. A distinct design of magneto-fluorescent nanoparticles can render the particle specific for certain macrophage polarizations [224]. The application of SPIO for TAM imaging has been extensively reviewed elsewhere [225]. The advantage of the SPIO approach is that there are particles that have been clinically approved for liver MR imaging carrying a very low toxic potential. In a first-in-patient trial of ferumoxytol, enhanced MRI showed that MR signal enhancement correlated with the presence of $\mathrm{CD} 8^{+} \mathrm{CD} 163^{+} \mathrm{TAMs}$ [226]. Intriguing was the report that clinically approved SPIOs not only enable imaging TAMs in vivo non-invasively but that they similarly inhibit tumor growth by triggering a pro-inflammatory TAM polarization with the TME. The authors conclude that ferumoxytol thereby might protect subsequent organs from metastatic seeds or potentiate macrophage-modulating cancer immunotherapies [227].

TAM tracking with SPIO by MR imaging similarly underlies some major limitations. First, direct (ex vivo) as well as in vivo labeling of monocyte/macrophages with iron oxide nanoparticles is non-specific to TAMs. Many other cells, such as neutrophils, carry some (although reduced) phagocytic potential. Especially organs with a physiologically high amount of resident phagocytic cells such as the liver (Kupfer cells) limit the specificity of such TAM imaging approaches. Second, image signal quantification of T2* MRI is highly complex and incomplete as frequently there is a non-linear correlation between local nanoparticle concentration and the obtained imaging signal. This lack of quantification can be improved by adding ex vivo mass spectrometry imaging such as laser ablation inductively coupled plasma mass spectrometry to in-vivo MRI. Applying a customized ${ }^{57}$ Fe based SPIO (instead of using 56Fe, which is highly abundant in hemoglobin, myo- 
globin etc.) Masthoff and Faber showed that spatially resolved maps of local nanoparticle distribution can be used to correct the in vivo imaging results, thereby improving quantification [228,229]. Third, noninvasive whole-body imaging is confined to cell tracking and assessing the gross magnitude of immune response in cancer. However, until now, nanoparticle MRI is not able to depict interactions of TAMs with other components of the TME. These cellular and subcellular processes can only be investigated by means of intravital microscopy, such as confocal or multi-photon approaches. Although the spatial resolution of MRI in principle would be sufficient to depict molecular processes at cellular resolution, the temporal resolution until now is not able to capture immune cell dynamics in real-time. Novel time-lapse MRI, by creating video-like loops of SPIO-labeled immune cells within the circulation, may overcome this limitation in the future and capture moving monocytes in situ [230]. Table 3 is summarizing the actual targets and probes used for TAM imaging.

Table 3. Target molecules and myeloid-specific processes used for TAM-specific imaging.

\begin{tabular}{ccc}
\hline Target Process/Molecule & Modality & Tracer \\
\hline Phagocytosis & MRI, PET, optic, hybrid & $\begin{array}{c}\text { Iron oxide nanoparticles [231], }{ }^{64} \text { Cu-labeled polyglucose } \\
\text { nanoparticle (macrin) [232], Cy5.5-VEGF [233], } \\
\text { perfluorocarbon (PFC) [234] }\end{array}$ \\
\hline Endocytosis & PET & ${ }^{89}$ Zr-PL-HDL, ${ }^{89}$ Zr-AI-HDL [215] \\
\hline F4/80 & Flow cytometry, fluorescence microscopy & ${ }^{111}$ In- $\alpha$ F4/80-A3-1 mAb [235] \\
\hline CD11b & PET & ${ }^{18}$ F-VHHDC13 [236] \\
\hline MHC-II & PET & ${ }^{18}$ F-VHH7 [236] \\
\hline CD206 & PET & $\gamma$-Tilmanocept [237], 18F-FB-anti-MMR 3.49 sdAb [238] \\
\hline CD163 & PET & ${ }^{68}$ Ga- $\alpha C D 163-m A b ~[239]$ \\
\hline TSPO & PET & ${ }^{18}$ F-GE-180 [240], ${ }^{18}$ F-DPA-714 [241], ${ }^{11 C-P B R 28 ~[242] ~}$ \\
\hline FR- $\beta$ & SPECT, PET & $3^{\prime}-$ Aza-2 $\left[{ }^{18}\right.$ F]fluorofolic acid [243]
\end{tabular}

Restricted to the preclinical setting, reporter gene imaging is additionally promising to assess TAM presence and activity in vivo. Activated luciferase-expressing macrophages created using the Cre-Lox system could be tracked in murine melanoma and breast cancer models [244]. Choi et al. were able to visualize the migration of TAMs to solid tumor lesions and evaluated the effect of anti-inflammatory therapy on the TME in a murine colon cancer model [245]. Putting a luciferase reporter under the control of the Arg1 promotor, indicative of M2 polarization, enabled bioluminescence tracking of adopted macrophages migrating toward the TME, thus allowing to investigate of even TAM polarization in vivo by gene reporter imaging [246].

\section{Perspective}

Macrophages represent the largest pool of immune cells in solid tumors, and different types of macrophages with divergent functions were identified so far. Depending on their profile and function, they are categorized into tumor-promoting or tumor-suppressive types. Results from several studies suggest that during early tumor manifestation and expansion, M1-type macrophages are the more dominant type. At late tumor stages, especially when metastases have already occurred, M2-type macrophages take over the scene. Several efforts are made to target tumor-associated macrophages by means of molecular imaging. Various methods exist that are able to track tumor-associated macrophages non-invasively. Specificity of the molecular probe toward a dedicated M1/M2 target, as well as a high sensitivity of the signal moiety of the imaging agent, is decisive for successful imaging of TAM dynamics in vivo. Molecular imaging thereby can help to better understand the time frames in which TAMs are specifically important during tumor growth and thus identify 
the optimal time points for TAM-directed therapies. Thereby, molecular TAM imaging can play a significant role within the precision medicine conundrum: to treat the right patient with the right drug at the right time point. Additionally, methodologies from molecular TAM imaging can be used in theranostic approaches, where imaging and reprogramming of TAMs can occur at the same time.

Funding: This research received no external funding.

Institutional Review Board Statement: Not applicable.

Informed Consent Statement: Not applicable.

Data Availability Statement: Not applicable.

Conflicts of Interest: The authors declare no conflict of interest.

\section{References}

1. Stratton, M.R. Exploring the Genomes of Cancer Cells: Progress and Promise. Science 2011, 331, 1553-1558. [CrossRef] [PubMed]

2. Marcus, A.; Gowen, B.G.; Thompson, T.W.; Iannello, A.; Ardolino, M.; Deng, W.; Wang, L.; Shifrin, N.; Raulet, D.H. Chapter Three Recognition of Tumors by the Innate Immune System and Natural Killer Cells. Adv. Immunol. 2014, 122, 91-128. [CrossRef] [PubMed]

3. Duan, Q.; Zhang, H.; Zheng, J.; Zhang, L. Turning Cold into Hot: Firing up the Tumor Microenvironment. Trends Cancer 2020, 6, 605-618. [CrossRef] [PubMed]

4. Nagelkerke, A.; Bussink, J.; Rowan, A.E.; Span, P.N. The Mechanical Microenvironment in Cancer: How Physics Affects Tumours. Semin. Cancer Biol. 2015, 35, 62-70. [CrossRef] [PubMed]

5. Ferrao, P.T.; Behren, A.; Anderson, R.L.; Thompson, E.W. Editorial: Cellular and Phenotypic Plasticity in Cancer. Front. Oncol. 2015, 5, 171. [CrossRef]

6. Rice, A.J.; Cortes, E.; Lachowski, D.; Cheung, B.C.H.; Karim, S.A.; Morton, J.P.; del Rio Hernández, A. Matrix Stiffness Induces Epithelial-Mesenchymal Transition and Promotes Chemoresistance in Pancreatic Cancer Cells. Oncogenesis 2017, 6, e352. [CrossRef]

7. Choquet, D.; Felsenfeld, D.P.; Sheetz, M.P. Extracellular Matrix Rigidity Causes Strengthening of Integrin-Cytoskeleton Linkages. Cell 1997, 88, 39-48. [CrossRef]

8. Labani-Motlagh, A.; Ashja-Mahdavi, M.; Loskog, A. The Tumor Microenvironment: A Milieu Hindering and Obstructing Antitumor Immune Responses. Front. Immunol. 2020, 11, 940. [CrossRef]

9. Lau, A.N.; Heiden, M.G.V. Metabolism in the Tumor Microenvironment. Annu. Rev. Cancer Biol. 2019, 4, 1-24. [CrossRef]

10. Vito, A.; El-Sayes, N.; Mossman, K. Hypoxia-Driven Immune Escape in the Tumor Microenvironment. Cells $2020,9,992$. [CrossRef]

11. Bhattacharya, S.; Calar, K.; de la Puente, P. Mimicking Tumor Hypoxia and Tumor-Immune Interactions Employing ThreeDimensional in Vitro Models. J. Exp. Clin. Cancer Res. 2020, 39, 75. [CrossRef]

12. Wang, W.; Wang, L.; Ruan, L.; Oh, J.; Dong, X.; Zhuge, Q.; Su, D.-M. Extracellular Vesicles Extracted from Young Donor Serum Attenuate Inflammaging via Partially Rejuvenating Aged T-cell Immunotolerance. FASEB J. 2018, 32, 5899-5912. [CrossRef]

13. Li, I.; Nabet, B.Y. Exosomes in the Tumor Microenvironment as Mediators of Cancer Therapy Resistance. Mol. Cancer 2019, 18, 32. [CrossRef]

14. Dai, J.; Su, Y.; Zhong, S.; Cong, L.; Liu, B.; Yang, J.; Tao, Y.; He, Z.; Chen, C.; Jiang, Y. Exosomes: Key Players in Cancer and Potential Therapeutic Strategy. Signal. Transduct. Target. Ther. 2020, 5, 145. [CrossRef]

15. Vilgelm, A.E.; Richmond, A. Chemokines Modulate Immune Surveillance in Tumorigenesis, Metastasis, and Response to Immunotherapy. Front. Immunol. 2019, 10, 333. [CrossRef]

16. Atretkhany, K.-S.N.; Drutskaya, M.S.; Nedospasov, S.A.; Grivennikov, S.I.; Kuprash, D.V. Chemokines, Cytokines and Exosomes Help Tumors to Shape Inflammatory Microenvironment. Pharmacol. Therapeut. 2016, 168, 98-112. [CrossRef]

17. Xiao, Z.; Dai, Z.; Locasale, J.W. Metabolic Landscape of the Tumor Microenvironment at Single Cell Resolution. Nat. Commun. 2019, 10, 3763. [CrossRef]

18. Jin, M.-Z.; Jin, W.-L. The Updated Landscape of Tumor Microenvironment and Drug Repurposing. Signal. Transduct. Target. Ther. 2020, 5, 166. [CrossRef]

19. Murciano-Goroff, Y.R.; Warner, A.B.; Wolchok, J.D. The Future of Cancer Immunotherapy: Microenvironment-Targeting Combinations. Cell Res. 2020, 30, 507-519. [CrossRef]

20. Popel, A.S. Immunoactivating the Tumor Microenvironment Enhances Immunotherapy as Predicted by Integrative Computational Model. Proc. Natl. Acad. Sci. USA 2020, 117, 4447-4449. [CrossRef]

21. Mpekris, F.; Voutouri, C.; Baish, J.W.; Duda, D.G.; Munn, L.L.; Stylianopoulos, T.; Jain, R.K. Combining Microenvironment Normalization Strategies to Improve Cancer Immunotherapy. Proc. Natl. Acad. Sci. USA 2020, 117, 3728-3737. [CrossRef]

22. Zheng, J.; Gao, P. Toward Normalization of the Tumor Microenvironment for Cancer Therapy. Integr. Cancer Ther. 2019, 18, 1534735419862352. [CrossRef] 
23. Jain, R.K. Normalizing Tumor Microenvironment to Treat Cancer: Bench to Bedside to Biomarkers. J. Clin. Oncol. 2013, 31, 2205-2218. [CrossRef] [PubMed]

24. Colotta, F.; Allavena, P.; Sica, A.; Garlanda, C.; Mantovani, A. Cancer-Related Inflammation, the Seventh Hallmark of Cancer: Links to Genetic Instability. Carcinogenesis 2009, 30, 1073-1081. [CrossRef] [PubMed]

25. Hanahan, D.; Weinberg, R.A. Hallmarks of Cancer: The Next Generation. Cell 2011, 144, 646-674. [CrossRef]

26. Teng, M.W.L.; Galon, J.; Fridman, W.-H.; Smyth, M.J. From Mice to Humans: Developments in Cancer Immunoediting. J. Clin. Investig. 2015, 125, 3338-3346. [CrossRef] [PubMed]

27. Vesely, M.D.; Kershaw, M.H.; Schreiber, R.D.; Smyth, M.J. Natural Innate and Adaptive Immunity to Cancer. Annu. Rev. Immunol. 2011, 29, 235-271. [CrossRef] [PubMed]

28. Gonzalez, H.; Hagerling, C.; Werb, Z. Roles of the Immune System in Cancer: From Tumor Initiation to Metastatic Progression. Gene Dev. 2018, 32, 1267-1284. [CrossRef] [PubMed]

29. Ostroumov, D.; Fekete-Drimusz, N.; Saborowski, M.; Kühnel, F.; Woller, N. CD4 and CD8 T Lymphocyte Interplay in Controlling Tumor Growth. Cell. Mol. Life Sci. 2017, 75, 689-713. [CrossRef] [PubMed]

30. Tomić, S.; Joksimović, B.; Bekić, M.; Vasiljević, M.; Milanović, M.; Čolić, M.; Vučević, D. Prostaglanin-E2 Potentiates the Suppressive Functions of Human Mononuclear Myeloid-Derived Suppressor Cells and Increases Their Capacity to Expand IL-10-Producing Regulatory T Cell Subsets. Front. Immunol. 2019, 10, 475. [CrossRef]

31. Batlle, E.; Massagué, J. Transforming Growth Factor- $\beta$ Signaling in Immunity and Cancer. Immunity 2019, 50, 924-940. [CrossRef]

32. Tamura, R.; Tanaka, T.; Akasaki, Y.; Murayama, Y.; Yoshida, K.; Sasaki, H. The Role of Vascular Endothelial Growth Factor in the Hypoxic and Immunosuppressive Tumor Microenvironment: Perspectives for Therapeutic Implications. Med. Oncol. 2019, 37, 2. [CrossRef]

33. Cervantes-Villagrana, R.D.; Albores-García, D.; Cervantes-Villagrana, A.R.; García-Acevez, S.J. Tumor-Induced Neurogenesis and Immune Evasion as Targets of Innovative Anti-Cancer Therapies. Signal. Transduct. Target. Ther. 2020, 5, 99. [CrossRef]

34. Nagarsheth, N.; Wicha, M.S.; Zou, W. Chemokines in the Cancer Microenvironment and Their Relevance in Cancer Immunotherapy. Nat. Rev. Immunol. 2017, 17, 559-572. [CrossRef]

35. Kitamura, T.; Qian, B.-Z.; Pollard, J.W. Immune Cell Promotion of Metastasis. Nat. Rev. Immunol. 2015, 15, 73-86. [CrossRef]

36. Zemek, R.M.; Chin, W.L.; Nowak, A.K.; Millward, M.J.; Lake, R.A.; Lesterhuis, W.J. Sensitizing the Tumor Microenvironment to Immune Checkpoint Therapy. Front. Immunol. 2020, 11, 223. [CrossRef]

37. Zhang, J.; Shi, Z.; Xu, X.; Yu, Z.; Mi, J. The Influence of Microenvironment on Tumor Immunotherapy. FEBS J. 2019, $286,4160-4175$. [CrossRef]

38. Guilliams, M.; Mildner, A.; Yona, S. Developmental and Functional Heterogeneity of Monocytes. Immunity 2018, 49, 595-613. [CrossRef] [PubMed]

39. Trzebanski, S.; Jung, S. Plasticity of Monocyte Development and Monocyte Fates. Immunol. Lett. 2020, 227, 66-78. [CrossRef]

40. Paul, W.E. Bridging Innate and Adaptive Immunity. Cell 2011, 147, 1212-1215. [CrossRef]

41. Olingy, C.E.; Dinh, H.Q.; Hedrick, C.C. Monocyte Heterogeneity and Functions in Cancer. J. Leukoc. Biol. 2019, 106, 309-322. [CrossRef] [PubMed]

42. Canè, S.; Ugel, S.; Trovato, R.; Marigo, I.; Sanctis, F.D.; Sartoris, S.; Bronte, V. The Endless Saga of Monocyte Diversity. Front. Immunol. 2019, 10, 1786. [CrossRef] [PubMed]

43. Patel, A.A.; Zhang, Y.; Fullerton, J.N.; Boelen, L.; Rongvaux, A.; Maini, A.A.; Bigley, V.; Flavell, R.A.; Gilroy, D.W.; Asquith, B.; et al. The Fate and Lifespan of Human Monocyte Subsets in Steady State and Systemic InflammationHuman Monocyte Kinetics. J. Exp. Med. 2017, 214, 1913-1923. [CrossRef] [PubMed]

44. Kapellos, T.S.; Bonaguro, L.; Gemünd, I.; Reusch, N.; Saglam, A.; Hinkley, E.R.; Schultze, J.L. Human Monocyte Subsets and Phenotypes in Major Chronic Inflammatory Diseases. Front. Immunol. 2019, 10, 2035. [CrossRef]

45. Kratofil, R.M.; Kubes, P.; Deniset, J.F. Monocyte Conversion during Inflammation and Injury. Arterioscler. Thromb. Vasc Biol. 2017, 37, 35-42. [CrossRef]

46. Buscher, K.; Marcovecchio, P.; Hedrick, C.C.; Ley, K. Patrolling Mechanics of Non-Classical Monocytes in Vascular Inflammation. Front. Cardiovasc. Med. 2017, 4, 80. [CrossRef]

47. Grage-Griebenow, E.; Flad, H.-D.; Ernst, M. Heterogeneity of Human Peripheral Blood Monocyte Subsets. J. Leukoc. Biol. 2001, 69, 11-20. [CrossRef]

48. Merah-Mourah, F.; Cohen, S.O.; Charron, D.; Mooney, N.; Haziot, A. Identification of Novel Human Monocyte Subsets and Evidence for Phenotypic Groups Defined by Interindividual Variations of Expression of Adhesion Molecules. Sci. Rep. 2020, 10, 4397. [CrossRef]

49. Sanford, D.E.; Belt, B.A.; Panni, R.Z.; Mayer, A.; Deshpande, A.D.; Carpenter, D.; Mitchem, J.B.; Plambeck-Suess, S.M.; Worley, L.A.; Goetz, B.D.; et al. Inflammatory Monocyte Mobilization Decreases Patient Survival in Pancreatic Cancer: A Role for Targeting the CCL2/CCR2 Axis. Clin. Cancer Res. 2013, 19, 3404-3415. [CrossRef]

50. Auffray, C.; Fogg, D.; Garfa, M.; Elain, G.; Join-Lambert, O.; Kayal, S.; Sarnacki, S.; Cumano, A.; Lauvau, G.; Geissmann, F. Monitoring of Blood Vessels and Tissues by a Population of Monocytes with Patrolling Behavior. Science 2007, 317, 666-670. [CrossRef] 
51. Bianchini, M.; Duchêne, J.; Santovito, D.; Schloss, M.J.; Evrard, M.; Winkels, H.; Aslani, M.; Mohanta, S.K.; Horckmans, M.; Blanchet, X.; et al. PD-L1 Expression on Nonclassical Monocytes Reveals Their Origin and Immunoregulatory Function. Sci. Immunol. 2019, 4, eaar3054. [CrossRef]

52. Satoh, T.; Nakagawa, K.; Sugihara, F.; Kuwahara, R.; Ashihara, M.; Yamane, F.; Minowa, Y.; Fukushima, K.; Ebina, I.; Yoshioka, Y.; et al. Identification of an Atypical Monocyte and Committed Progenitor Involved in Fibrosis. Nature 2017, 541, 96-101. [CrossRef]

53. Gabrilovich, D.I. Myeloid-Derived Suppressor Cells. Cancer Immunol. Res. 2017, 5, 3-8. [CrossRef]

54. Furusawa, J.; Mizoguchi, I.; Chiba, Y.; Hisada, M.; Kobayashi, F.; Yoshida, H.; Nakae, S.; Tsuchida, A.; Matsumoto, T.; Ema, H.; et al. Promotion of Expansion and Differentiation of Hematopoietic Stem Cells by Interleukin-27 into Myeloid Progenitors to Control Infection in Emergency Myelopoiesis. PLoS Pathog. 2016, 12, e1005507. [CrossRef]

55. Mandruzzato, S.; Brandau, S.; Britten, C.M.; Bronte, V.; Damuzzo, V.; Gouttefangeas, C.; Maurer, D.; Ottensmeier, C.; van der Burg, S.H.; Welters, M.J.P.; et al. Toward Harmonized Phenotyping of Human Myeloid-Derived Suppressor Cells by Flow Cytometry: Results from an Interim Study. Cancer Immunol. Immunother. 2016, 65, 161-169. [CrossRef]

56. Haile, L.A.; Greten, T.F.; Korangy, F. Immune Suppression: The Hallmark of Myeloid Derived Suppressor Cells. Immunol. Investig. 2012, 41, 581-594. [CrossRef]

57. Yang, Y.; Li, C.; Liu, T.; Dai, X.; Bazhin, A.V. Myeloid-Derived Suppressor Cells in Tumors: From Mechanisms to Antigen Specificity and Microenvironmental Regulation. Front. Immunol. 2020, 11, 1371. [CrossRef]

58. Bruse, N.; Leijte, G.P.; Pickkers, P.; Kox, M. New Frontiers in Precision Medicine for Sepsis-Induced Immunoparalysis. Expert Rev. Clin. Immunol. 2018, 15, 251-263. [CrossRef]

59. Schrijver, I.T.; Théroude, C.; Roger, T. Myeloid-Derived Suppressor Cells in Sepsis. Front. Immunol. 2019, 10, 327. [CrossRef]

60. Davidov, V.; Jensen, G.; Mai, S.; Chen, S.-H.; Pan, P.-Y. Analyzing One Cell at a TIME: Analysis of Myeloid Cell Contributions in the Tumor Immune Microenvironment. Front. Immunol. 2020, 11, 1842. [CrossRef]

61. Sica, A.; Bronte, V. Altered Macrophage Differentiation and Immune Dysfunction in Tumor Development. J. Clin. Investig. 2007, 117, 1155-1166. [CrossRef]

62. Lee, W.-C.; Hsu, P.-Y.; Hsu, H.-Y. Stem Cell Factor Produced by Tumor Cells Expands Myeloid-Derived Suppressor Cells in Mice. Sci. Rep. 2020, 10, 11257. [CrossRef]

63. Horikawa, N.; Abiko, K.; Matsumura, N.; Hamanishi, J.; Baba, T.; Yamaguchi, K.; Yoshioka, Y.; Koshiyama, M.; Konishi, I. Expression of Vascular Endothelial Growth Factor in Ovarian Cancer Inhibits Tumor Immunity through the Accumulation of Myeloid-Derived Suppressor Cells. Clin. Cancer Res. 2017, 23, 587-599. [CrossRef]

64. Johnson, B.S.; Mueller, L.; Si, J.; Collins, S.J. The Cytokines IL-3 and GM-CSF Regulate the Transcriptional Activity of Retinoic Acid Receptors in Different in Vitro Models of Myeloid Differentiation. Blood 2002, 99, 746-753. [CrossRef]

65. Jiang, M.; Chen, J.; Zhang, W.; Zhang, R.; Ye, Y.; Liu, P.; Yu, W.; Wei, F.; Ren, X.; Yu, J. Interleukin-6 Trans-Signaling Pathway Promotes Immunosuppressive Myeloid-Derived Suppressor Cells via Suppression of Suppressor of Cytokine Signaling 3 in Breast Cancer. Front. Immunol. 2017, 8, 1840. [CrossRef]

66. Tobin, R.P.; Jordan, K.R.; Kapoor, P.; Spongberg, E.; Davis, D.; Vorwald, V.M.; Couts, K.L.; Gao, D.; Smith, D.E.; Borgers, J.S.W.; et al. IL-6 and IL-8 Are Linked With Myeloid-Derived Suppressor Cell Accumulation and Correlate With Poor Clinical Outcomes in Melanoma Patients. Front. Oncol. 2019, 9, 1223. [CrossRef]

67. Zhao, F.; Hoechst, B.; Duffy, A.; Gamrekelashvili, J.; Fioravanti, S.; Manns, M.P.; Greten, T.F.; Korangy, F. S100A9 a New Marker for Monocytic Human Myeloid-derived Suppressor Cells. Immunology 2012, 136, 176-183. [CrossRef]

68. Lim, S.Y.; Yuzhalin, A.E.; Gordon-Weeks, A.N.; Muschel, R.J. Tumor-Infiltrating Monocytes/Macrophages Promote Tumor Invasion and Migration by Upregulating S100A8 and S100A9 Expression in Cancer Cells. Oncogene 2016, 35, 5735-5745. [CrossRef] [PubMed]

69. Gabrilovich, D.I.; Nagaraj, S. Myeloid-Derived Suppressor Cells as Regulators of the Immune System. Nat. Rev. Immunol. 2009, 9, 162-174. [CrossRef] [PubMed]

70. Umemura, N.; Saio, M.; Suwa, T.; Kitoh, Y.; Bai, J.; Nonaka, K.; Ouyang, G.; Okada, M.; Balazs, M.; Adany, R.; et al. Tumorinfiltrating Myeloid-derived Suppressor Cells Are Pleiotropic-inflamed Monocytes/Macrophages That Bear M1- and M2-type Characteristics. J. Leukoc. Biol. 2008, 83, 1136-1144. [CrossRef] [PubMed]

71. Ma, G.; Pan, P.-Y.; Eisenstein, S.; Divino, C.M.; Lowell, C.A.; Takai, T.; Chen, S.-H. Paired Immunoglobin-like Receptor-B Regulates the Suppressive Function and Fate of Myeloid-Derived Suppressor Cells. Immunity 2011, 34, 385-395. [CrossRef]

72. He, W.; Liang, P.; Guo, G.; Huang, Z.; Niu, Y.; Dong, L.; Wang, C.; Zhang, J. Re-Polarizing Myeloid-Derived Suppressor Cells (MDSCs) with Cationic Polymers for Cancer Immunotherapy. Sci. Rep. 2016, 6, 24506. [CrossRef]

73. Ochando, J.C.; Chen, S.H. Myeloid-Derived Suppressor Cells in Transplantation and Cancer. Immunol. Res. 2012, 54, 275-285. [CrossRef]

74. Yang, W.-C.; Ma, G.; Chen, S.-H.; Pan, P.-Y. Polarization and Reprogramming of Myeloid-Derived Suppressor Cells. J. Mol. Cell Biol. 2013, 5, 207-209. [CrossRef]

75. Elliott, L.A.; Doherty, G.A.; Sheahan, K.; Ryan, E.J. Human Tumor-Infiltrating Myeloid Cells: Phenotypic and Functional Diversity. Front. Immunol. 2017, 8, 86. [CrossRef]

76. Laviron, M.; Boissonnas, A. Ontogeny of Tumor-Associated Macrophages. Front. Immunol. 2019, 10, 1799. [CrossRef]

77. Zhang, B.; Wang, Z.; Wu, L.; Zhang, M.; Li, W.; Ding, J.; Zhu, J.; Wei, H.; Zhao, K. Circulating and Tumor-Infiltrating MyeloidDerived Suppressor Cells in Patients with Colorectal Carcinoma. PLoS ONE 2013, 8, e57114. [CrossRef] 
78. Mahmoud, S.M.A.; Lee, A.H.S.; Paish, E.C.; Macmillan, R.D.; Ellis, I.O.; Green, A.R. Tumour-Infiltrating Macrophages and Clinical Outcome in Breast Cancer. J. Clin. Pathol. 2012, 65, 159. [CrossRef]

79. Fogg, D.K.; Sibon, C.; Miled, C.; Jung, S.; Aucouturier, P.; Littman, D.R.; Cumano, A.; Geissmann, F. A Clonogenic Bone Marrow Progenitor Specific for Macrophages and Dendritic Cells. Science 2006, 311, 83-87. [CrossRef]

80. Hettinger, J.; Richards, D.M.; Hansson, J.; Barra, M.M.; Joschko, A.-C.; Krijgsveld, J.; Feuerer, M. Origin of Monocytes and Macrophages in a Committed Progenitor. Nat. Immunol. 2013, 14, 821-830. [CrossRef]

81. Ginhoux, F.; Guilliams, M. Tissue-Resident Macrophage Ontogeny and Homeostasis. Immunity 2016, 44, 439-449. [CrossRef]

82. Theret, M.; Mounier, R.; Rossi, F. The Origins and Non-Canonical Functions of Macrophages in Development and Regeneration. Development 2019, 146, dev156000. [CrossRef]

83. Linehan, E.; Fitzgerald, D. Ageing and the Immune System: Focus on Macrophages. Eur. J. Microbiol. Immunol. 2015, 5, 14-24. [CrossRef]

84. Ajami, B.; Bennett, J.L.; Krieger, C.; Tetzlaff, W.; Rossi, F.M.V. Local Self-Renewal Can Sustain CNS Microglia Maintenance and Function throughout Adult Life. Nat. Neurosci. 2007, 10, 1538-1543. [CrossRef]

85. Epelman, S.; Lavine, K.J.; Beaudin, A.E.; Sojka, D.K.; Carrero, J.A.; Calderon, B.; Brija, T.; Gautier, E.L.; Ivanov, S.; Satpathy, A.T.; et al. Embryonic and Adult-Derived Resident Cardiac Macrophages Are Maintained through Distinct Mechanisms at Steady State and during Inflammation. Immunity 2014, 40, 91-104. [CrossRef]

86. Huang, Y.; Xu, Z.; Xiong, S.; Sun, F.; Qin, G.; Hu, G.; Wang, J.; Zhao, L.; Liang, Y.-X.; Wu, T.; et al. Repopulated Microglia Are Solely Derived from the Proliferation of Residual Microglia after Acute Depletion. Nat. Neurosci. 2018, 21, 530-540. [CrossRef]

87. Guillot, A.; Tacke, F. Liver Macrophages: Old Dogmas and New Insights. Hepatol. Commun. 2019, 3, 730-743. [CrossRef] [PubMed]

88. MacParland, S.A.; Liu, J.C.; Ma, X.-Z.; Innes, B.T.; Bartczak, A.M.; Gage, B.K.; Manuel, J.; Khuu, N.; Echeverri, J.; Linares, I.; et al. Single Cell RNA Sequencing of Human Liver Reveals Distinct Intrahepatic Macrophage Populations. Nat. Commun. 2018, 9, 4383. [CrossRef] [PubMed]

89. Su, L.; Li, N.; Tang, H.; Lou, Z.; Chong, X.; Zhang, C.; Su, J.; Dong, X. Kupffer Cell-Derived TNF- $\alpha$ Promotes Hepatocytes to Produce CXCL1 and Mobilize Neutrophils in Response to Necrotic Cells. Cell Death Dis. 2018, 9, 323. [CrossRef] [PubMed]

90. Dai, S.; Liu, F.; Qin, Z.; Zhang, J.; Chen, J.; Ding, W.-X.; Feng, D.; Ji, Y.; Qin, X. Kupffer Cells Promote T-Cell Hepatitis by Producing CXCL10 and Limiting Liver Sinusoidal Endothelial Cell Permeability. Theranostics 2020, 10, 7163-7177. [CrossRef]

91. Blériot, C.; Dupuis, T.; Jouvion, G.; Eberl, G.; Disson, O.; Lecuit, M. Liver-Resident Macrophage Necroptosis Orchestrates Type 1 Microbicidal Inflammation and Type-2-Mediated Tissue Repair during Bacterial Infection. Immunity 2015, 42, 145-158. [CrossRef]

92. Mass, E.; Ballesteros, I.; Farlik, M.; Halbritter, F.; Günther, P.; Crozet, L.; Jacome-Galarza, C.E.; Händler, K.; Klughammer, J.; Kobayashi, Y.; et al. Specification of Tissue-Resident Macrophages during Organogenesis. Science 2016, 353, aaf4238. [CrossRef]

93. Wang, J.; Kubes, P. A Reservoir of Mature Cavity Macrophages That Can Rapidly Invade Visceral Organs to Affect Tissue Repair. Cell 2016, 165, 668-678. [CrossRef]

94. Swirski, F.K.; Nahrendorf, M.; Etzrodt, M.; Wildgruber, M.; Cortez-Retamozo, V.; Panizzi, P.; Figueiredo, J.-L.; Kohler, R.H.; Chudnovskiy, A.; Waterman, P.; et al. Identification of Splenic Reservoir Monocytes and Their Deployment to Inflammatory Sites. Science 2009, 325, 612-616. [CrossRef]

95. Aoyama, T.; Kuwahara-Arai, K.; Uchiyama, A.; Kon, K.; Okubo, H.; Yamashina, S.; Ikejima, K.; Kokubu, S.; Miyazaki, A.; Watanabe, S. Spleen-Derived Lipocalin-2 in the Portal Vein Regulates Kupffer Cells Activation and Attenuates the Development of Liver Fibrosis in Mice. Lab. Investig. 2017, 97, 890-902. [CrossRef]

96. Li, L.; Wei, W.; Li, Z.; Chen, H.; Li, Y.; Jiang, W.; Chen, W.; Kong, G.; Yang, J.; Li, Z. The Spleen Promotes the Secretion of CCL2 and Supports an M1 Dominant Phenotype in Hepatic Macrophages During Liver Fibrosis. Cell Physiol. Biochem. 2018, 51, 557-574. [CrossRef]

97. Cortez-Retamozo, V.; Etzrodt, M.; Newton, A.; Ryan, R.; Pucci, F.; Sio, S.W.; Kuswanto, W.; Rauch, P.J.; Chudnovskiy, A.; Iwamoto, Y.; et al. Angiotensin II Drives the Production of Tumor-Promoting Macrophages. Immunity 2013, 38, 296-308. [CrossRef]

98. Wu, C.; Hua, Q.; Zheng, L. Generation of Myeloid Cells in Cancer: The Spleen Matters. Front. Immunol. 2020, 11, 1126. [CrossRef]

99. Long, X.; Wang, J.; Zhao, J.; Liang, H.; Zhu, P.; Cheng, Q.; Chen, Q.; Wu, Y.; Zhang, Z.; Zhang, B.; et al. Splenectomy Suppresses Growth and Metastasis of Hepatocellular Carcinoma through Decreasing Myeloid-Derived Suppressor Cells in Vivo. J. Huazhong Univ. Sci. Technol. Med Sci. 2016, 36, 667-676. [CrossRef]

100. Sugase, T.; Lam, B.Q.; Danielson, M.; Terai, M.; Aplin, A.E.; Gutkind, J.S.; Sato, T. Development and Optimization of Orthotopic Liver Metastasis Xenograft Mouse Models in Uveal Melanoma. J. Transl. Med. 2020, 18, 208. [CrossRef]

101. Bercovici, N.; Guérin, M.V.; Trautmann, A.; Donnadieu, E. The Remarkable Plasticity of Macrophages: A Chance to Fight Cancer. Front. Immunol. 2019, 10, 1563. [CrossRef]

102. Ginhoux, F.; Schultze, J.L.; Murray, P.J.; Ochando, J.; Biswas, S.K. New Insights into the Multidimensional Concept of Macrophage Ontogeny, Activation and Function. Nat. Immunol. 2016, 17, 34-40. [CrossRef]

103. Cassetta, L.; Pollard, J.W. Repolarizing Macrophages Improves Breast Cancer Therapy. Cell Res. 2017, 27, 963-964. [CrossRef]

104. Vitale, I.; Manic, G.; Coussens, L.M.; Kroemer, G.; Galluzzi, L. Macrophages and Metabolism in the Tumor Microenvironment. Cell Metab. 2019, 30, 36-50. [CrossRef] 
105. Müller, S.; Kohanbash, G.; Liu, S.J.; Alvarado, B.; Carrera, D.; Bhaduri, A.; Watchmaker, P.B.; Yagnik, G.; Lullo, E.D.; Malatesta, M.; et al. Single-Cell Profiling of Human Gliomas Reveals Macrophage Ontogeny as a Basis for Regional Differences in Macrophage Activation in the Tumor Microenvironment. Genome Biol. 2017, 18, 234. [CrossRef]

106. Arora, S.; Dev, K.; Agarwal, B.; Das, P.; Syed, M.A. Macrophages: Their Role, Activation and Polarization in Pulmonary Diseases. Immunobiology 2018, 223, 383-396. [CrossRef]

107. Wang, L.; Zhang, S.; Wu, H.; Rong, X.; Guo, J. M2b Macrophage Polarization and Its Roles in Diseases. J. Leukoc. Biol. 2019, 106, 345-358. [CrossRef]

108. Mantovani, A.; Sica, A.; Sozzani, S.; Allavena, P.; Vecchi, A.; Locati, M. The Chemokine System in Diverse Forms of Macrophage Activation and Polarization. Trends Immunol. 2004, 25, 677-686. [CrossRef]

109. Mosser, D.M.; Edwards, J.P. Exploring the Full Spectrum of Macrophage Activation. Nat. Rev. Immunol. 2008, 8, 958-969. [CrossRef]

110. Rőszer, T. Understanding the Mysterious M2 Macrophage through Activation Markers and Effector Mechanisms. Mediat. Inflamm. 2015, 2015, 1-16. [CrossRef]

111. Chen, C.; Liu, J.; Luo, Y. MicroRNAs in Tumor Immunity: Functional Regulation in Tumor-Associated Macrophages. J. Zhejiang Univ. Sci. B 2020, 21, 12-28. [CrossRef] [PubMed]

112. Szebeni, G.J.; Vizler, C.; Kitajka, K.; Puskas, L.G. Inflammation and Cancer: Extra- and Intracellular Determinants of TumorAssociated Macrophages as Tumor Promoters. Mediat. Inflamm. 2017, 2017, 1-13. [CrossRef] [PubMed]

113. Curtale, G.; Rubino, M.; Locati, M. MicroRNAs as Molecular Switches in Macrophage Activation. Front. Immunol. 2019, 10, 799. [CrossRef] [PubMed]

114. Cai, X.; Yin, Y.; Li, N.; Zhu, D.; Zhang, J.; Zhang, C.-Y.; Zen, K. Re-Polarization of Tumor-Associated Macrophages to proInflammatory M1 Macrophages by MicroRNA. J. Mol. Cell Biol. 2012, 4, 341-343. [CrossRef]

115. Ying, H.; Kang, Y.; Zhang, H.; Zhao, D.; Xia, J.; Lu, Z.; Wang, H.; Xu, F.; Shi, L. MiR-127 Modulates Macrophage Polarization and Promotes Lung Inflammation and Injury by Activating the JNK Pathway. J. Immunol. 2015, 194, 1239-1251. [CrossRef]

116. Chaudhuri, A.A.; So, A.Y.-L.; Sinha, N.; Gibson, W.S.J.; Taganov, K.D.; O'Connell, R.M.; Baltimore, D. MicroRNA-125b Potentiates Macrophage Activation. J. Immunol. 2011, 187, 5062-5068. [CrossRef]

117. Wang, P.; Wang, H.; Huang, Q.; Peng, C.; Yao, L.; Chen, H.; Qiu, Z.; Wu, Y.; Wang, L.; Chen, W. Exosomes from M1-Polarized Macrophages Enhance Paclitaxel Antitumor Activity by Activating Macrophages-Mediated Inflammation. Theranostics 2019, 9 , 1714-1727. [CrossRef]

118. Qian, B.-Z.; Li, J.; Zhang, H.; Kitamura, T.; Zhang, J.; Campion, L.R.; Kaiser, E.A.; Snyder, L.A.; Pollard, J.W. CCL2 Recruits Inflammatory Monocytes to Facilitate Breast-Tumour Metastasis. Nature 2011, 475, 222-225. [CrossRef]

119. Pathria, P.; Louis, T.L.; Varner, J.A. Targeting Tumor-Associated Macrophages in Cancer. Trends Immunol. 2019, 40, 310-327. [CrossRef]

120. Scala, S. Molecular Pathways: Targeting the CXCR4-CXCL12 Axis-Untapped Potential in the Tumor Microenvironment. Clin. Cancer Res. 2015, 21, 4278-4285. [CrossRef]

121. Rogers, T.L.; Holen, I. Tumour Macrophages as Potential Targets of Bisphosphonates. J. Transl. Med. 2011, 9, 177. [CrossRef]

122. Gül, N.; Babes, L.; Siegmund, K.; Korthouwer, R.; Bögels, M.; Braster, R.; Vidarsson, G.; ten Hagen, T.L.M.; Kubes, P.; van Egmond, M. Macrophages Eliminate Circulating Tumor Cells after Monoclonal Antibody Therapy. J. Clin. Investig. 2014, 124, 812-823. [CrossRef]

123. Guerriero, J.L. Macrophages: The Road Less Traveled, Changing Anticancer Therapy. Trends Mol. Med. 2018, $24,472-489$. [CrossRef]

124. Mantovani, A.; Marchesi, F.; Malesci, A.; Laghi, L.; Allavena, P. Tumour-Associated Macrophages as Treatment Targets in Oncology. Nat. Rev. Clin. Oncol. 2017, 14, 399-416. [CrossRef]

125. Hu, G.; Guo, M.; Xu, J.; Wu, F.; Fan, J.; Huang, Q.; Yang, G.; Lv, Z.; Wang, X.; Jin, Y. Nanoparticles Targeting Macrophages as Potential Clinical Therapeutic Agents Against Cancer and Inflammation. Front. Immunol. 2019, 10, 1998. [CrossRef]

126. Wang, H.-F.; Liu, Y.; Yang, G.; Zhao, C.-X. Macrophage-Mediated Cancer Drug Delivery. Mater. Today Sustain. $2020,100055$. [CrossRef]

127. Xia, Y.; Rao, L.; Yao, H.; Wang, Z.; Ning, P.; Chen, X. Engineering Macrophages for Cancer Immunotherapy and Drug Delivery. Adv. Mater. 2020, 32, 2002054. [CrossRef]

128. Pettersen, J.S.; Fuentes-Duculan, J.; Suárez-Fariñas, M.; Pierson, K.C.; Pitts-Kiefer, A.; Fan, L.; Belkin, D.A.; Wang, C.Q.F.; Bhuvanendran, S.; Johnson-Huang, L.M.; et al. Tumor-Associated Macrophages in the Cutaneous SCC Microenvironment Are Heterogeneously Activated. J. Investig. Dermatol. 2011, 131, 1322-1330. [CrossRef]

129. Bertani, F.R.; Mozetic, P.; Fioramonti, M.; Iuliani, M.; Ribelli, G.; Pantano, F.; Santini, D.; Tonini, G.; Trombetta, M.; Businaro, L.; et al. Classification of M1/M2-Polarized Human Macrophages by Label-Free Hyperspectral Reflectance Confocal Microscopy and Multivariate Analysis. Sci. Rep. 2017, 7, 8965. [CrossRef]

130. Buechler, C.; Ritter, M.; Orsó, E.; Langmann, T.; Klucken, J.; Schmitz, G. Regulation of Scavenger Receptor CD163 Expression in Human Monocytes and Macrophages by Pro- and Antiinflammatory Stimuli. J. Leukoc. Biol. 2000, 67, 97-103. [CrossRef]

131. Koning, N.; van Eijk, M.; Pouwels, W.; Brouwer, M.S.M.; Voehringer, D.; Huitinga, I.; Hoek, R.M.; Raes, G.; Hamann, J. Expression of the Inhibitory CD200 Receptor Is Associated with Alternative Macrophage Activation. J. Innate Immun. 2010, 2, 195-200. [CrossRef] [PubMed] 
132. Xuan, W.; Qu, Q.; Zheng, B.; Xiong, S.; Fan, G. The Chemotaxis of M1 and M2 Macrophages Is Regulated by Different Chemokines. J. Leukoc. Biol. 2015, 97, 61-69. [CrossRef] [PubMed]

133. Ruytinx, P.; Proost, P.; Damme, J.V.; Struyf, S. Chemokine-Induced Macrophage Polarization in Inflammatory Conditions. Front. Immunol. 2018, 9, 1930. [CrossRef] [PubMed]

134. Conti, I.; Rollins, B.J. CCL2 (Monocyte Chemoattractant Protein-1) and Cancer. Semin. Cancer Biol. 2004, 14, 149-154. [CrossRef]

135. Biswas, S.K.; Mantovani, A. Macrophage Plasticity and Interaction with Lymphocyte Subsets: Cancer as a Paradigm. Nat. Immunol. 2010, 11, 889-896. [CrossRef]

136. Scheller, J.; Garbers, C.; Rose-John, S. Interleukin-6: From Basic Biology to Selective Blockade of pro-Inflammatory Activities. Semin. Immunol. 2014, 26, 2-12. [CrossRef]

137. Martinez, F.O.; Gordon, S. The M1 and M2 Paradigm of Macrophage Activation: Time for Reassessment. F1000prime Rep. 2014, 6, 13. [CrossRef]

138. Högger, P.; Dreier, J.; Droste, A.; Buck, F.; Sorg, C. Identification of the Integral Membrane Protein RM3/1 on Human Monocytes as a Glucocorticoid-Inducible Member of the Scavenger Receptor Cysteine-Rich Family (CD163). J. Immunol. 1998, 161, 1883-1890.

139. Murray, P.J.; Allen, J.E.; Biswas, S.K.; Fisher, E.A.; Gilroy, D.W.; Goerdt, S.; Gordon, S.; Hamilton, J.A.; Ivashkiv, L.B.; Lawrence, T.; et al. Macrophage Activation and Polarization: Nomenclature and Experimental Guidelines. Immunity 2014, 41, 14-20. [CrossRef]

140. Faulknor, R.A.; Olekson, M.A.; Ekwueme, E.C.; Krzyszczyk, P.; Freeman, J.W.; Berthiaume, F. Hypoxia Impairs Mesenchymal Stromal Cell-Induced Macrophage M1 to M2 Transition. Technology 2017, 05, 81-86. [CrossRef]

141. Zhao, G.; Liu, L.; Peek, R.M.; Hao, X.; Polk, D.B.; Li, H.; Yan, F. Activation of Epidermal Growth Factor Receptor in Macrophages Mediates Feedback Inhibition of M2 Polarization and Gastrointestinal Tumor Cell Growth. J. Biol. Chem. 2016, $291,20462-20472$. [CrossRef]

142. Zhu, Y.; Yang, J.; Xu, D.; Gao, X.-M.; Zhang, Z.; Hsu, J.L.; Li, C.-W.; Lim, S.-O.; Sheng, Y.-Y.; Zhang, Y.; et al. Disruption of Tumour-Associated Macrophage Trafficking by the Osteopontin-Induced Colony-Stimulating Factor-1 Signalling Sensitises Hepatocellular Carcinoma to Anti-PD-L1 Blockade. Gut 2019, 68, 1653. [CrossRef]

143. Zhang, F.; Wang, H.; Wang, X.; Jiang, G.; Liu, H.; Zhang, G.; Wang, H.; Fang, R.; Bu, X.; Cai, S.; et al. TGF- $\beta$ Induces M2-like Macrophage Polarization via SNAIL-Mediated Suppression of a pro-Inflammatory Phenotype. Oncotarget 2015, 7, 52294-52306. [CrossRef]

144. Chen, L.; Wang, S.; Wang, Y.; Zhang, W.; Ma, K.; Hu, C.; Zhu, H.; Liang, S.; Liu, M.; Xu, N. IL-6 Influences the Polarization of Macrophages and the Formation and Growth of Colorectal Tumor. Oncotarget 2018, 9, 17443-17454. [CrossRef]

145. Chuang, Y.; Hung, M.E.; Cangelose, B.K.; Leonard, J.N. Regulation of the IL-10-Driven Macrophage Phenotype under Incoherent Stimuli. Innate Immun. 2016, 22, 647-657. [CrossRef]

146. Benner, B.; Scarberry, L.; Suarez-Kelly, L.P.; Duggan, M.C.; Campbell, A.R.; Smith, E.; Lapurga, G.; Jiang, K.; Butchar, J.P.; Tridandapani, S.; et al. Generation of Monocyte-Derived Tumor-Associated Macrophages Using Tumor-Conditioned Media Provides a Novel Method to Study Tumor-Associated Macrophages in Vitro. J. Immunother. Cancer 2019, 7, 140. [CrossRef]

147. Lee, J.; Tam, H.; Adler, L.; Ilstad-Minnihan, A.; Macaubas, C.; Mellins, E.D. The MHC Class II Antigen Presentation Pathway in Human Monocytes Differs by Subset and Is Regulated by Cytokines. PLoS ONE 2017, 12, e0183594. [CrossRef]

148. Wang, B.; Li, Q.; Qin, L.; Zhao, S.; Wang, J.; Chen, X. Transition of Tumor-Associated Macrophages from MHC Class IIhi to MHC Class IIlow Mediates Tumor Progression in Mice. BMC Immunol. 2011, 12, 43. [CrossRef]

149. Wynn1, T.; Barron1, L.; Bataller, R.; Brenner, D.; Iredale, J.; Friedman, S.; Friedman, S.; Wallace, K.; Burt, A.; Wright, M.; et al. Macrophages: Master Regulators of Inflammation and Fibrosis. Semin. Liver Dis. 2010, 30, 245. [CrossRef]

150. Kwak, T.; Wang, F.; Deng, H.; Condamine, T.; Kumar, V.; Perego, M.; Kossenkov, A.; Montaner, L.J.; Xu, X.; Xu, W.; et al. Distinct Populations of Immune-Suppressive Macrophages Differentiate from Monocytic Myeloid-Derived Suppressor Cells in Cancer. Cell Rep. 2020, 33, 108571. [CrossRef]

151. Schelbergen, R.F.; Blom, A.B.; de Munter, W.; Vogl, T.; Roth, J.; van den Berg, W.B.; van Lent, P.L. Alarmins S100A8 and S100A9 Stimulate Production of Pro-Inflammatory Cytokines in M2 Macrophages without Changing Their M2 Membrane Phenotype. Ann. Rheum. Dis. 2012, 71, A76. [CrossRef]

152. Riabov, V.; Yin, S.; Song, B.; Avdic, A.; Schledzewski, K.; Ovsiy, I.; Gratchev, A.; Verdiell, M.L.; Sticht, C.; Schmuttermaier, C.; et al. Stabilin-1 Is Expressed in Human Breast Cancer and Supports Tumor Growth in Mammary Adenocarcinoma Mouse Model. Oncotarget 2015, 7, 31097-31110. [CrossRef] [PubMed]

153. Hollmén, M.; Figueiredo, C.R.; Jalkanen, S. New Tools to Prevent Cancer Growth and Spread: A 'Clever' Approach. Br. J. Cancer 2020, 123, 501-509. [CrossRef] [PubMed]

154. Lai, Y.; Wahyuningtyas, R.; Aui, S.; Chang, K. Autocrine VEGF Signalling on M2 Macrophages Regulates PD-L1 Expression for Immunomodulation of T Cells. J. Cell Mol. Med. 2019, 23, 1257-1267. [CrossRef]

155. Wu, W.-K.; Llewellyn, O.P.C.; Bates, D.O.; Nicholson, L.B.; Dick, A.D. IL-10 Regulation of Macrophage VEGF Production Is Dependent on Macrophage Polarisation and Hypoxia. Immunobiology 2010, 215, 796-803. [CrossRef]

156. Takeda, N.; O’Dea, E.L.; Doedens, A.; Kim, J.; Weidemann, A.; Stockmann, C.; Asagiri, M.; Simon, M.C.; Hoffmann, A.; Johnson, R.S. Differential Activation and Antagonistic Function of HIF- $\alpha$ Isoforms in Macrophages Are Essential for NO Homeostasis. Gene Dev. 2010, 24, 491-501. [CrossRef]

157. Huangfu, N.; Zheng, W.; Xu, Z.; Wang, S.; Wang, Y.; Cheng, J.; Li, Z.; Cheng, K.; Zhang, S.; Chen, X.; et al. RBM4 Regulates M1 Macrophages Polarization through Targeting STAT1-Mediated Glycolysis. Int. Immunopharmacol. 2020, 83, 106432. [CrossRef] 
158. Chistiakov, D.A.; Myasoedova, V.A.; Revin, V.V.; Orekhov, A.N.; Bobryshev, Y.V. The Impact of Interferon-Regulatory Factors to Macrophage Differentiation and Polarization into M1 and M2. Immunobiology 2018, 223, 101-111. [CrossRef]

159. Srivastava, M.; Saqib, U.; Naim, A.; Roy, A.; Liu, D.; Bhatnagar, D.; Ravinder, R.; Baig, M.S. The TLR4-NOS1-AP1 Signaling Axis Regulates Macrophage Polarization. Inflamm. Res. 2017, 66, 323-334. [CrossRef]

160. Raes, G.; Baetselier, P.D.; Noël, W.; Beschin, A.; Brombacher, F.; Gh, G.H. Differential Expression of FIZZ1 and Ym1 in Alternatively versus Classically Activated Macrophages. J. Leukoc. Biol. 2002, 71, 597-602. [CrossRef]

161. Welch, J.S.; Escoubet-Lozach, L.; Sykes, D.B.; Liddiard, K.; Greaves, D.R.; Glass, C.K. TH2 Cytokines and Allergic Challenge Induce Ym1 Expression in Macrophages by a STAT6-Dependent Mechanism. J. Biol. Chem. 2002, 277, 42821-42829. [CrossRef]

162. Satoh, T.; Takeuchi, O.; Vandenbon, A.; Yasuda, K.; Tanaka, Y.; Kumagai, Y.; Miyake, T.; Matsushita, K.; Okazaki, T.; Saitoh, T.; et al. The Jmjd3-Irf4 Axis Regulates M2 Macrophage Polarization and Host Responses against Helminth Infection. Nat. Immunol. 2010, 11, 936-944. [CrossRef]

163. Yin, Z.; Ma, T.; Lin, Y.; Lu, X.; Zhang, C.; Chen, S.; Jian, Z. IL-6/STAT3 Pathway Intermediates M1/M2 Macrophage Polarization during the Development of Hepatocellular Carcinoma. J. Cell Biochem. 2018, 119, 9419-9432. [CrossRef]

164. Shima, T.; Shimoda, M.; Shigenobu, T.; Ohtsuka, T.; Nishimura, T.; Emoto, K.; Hayashi, Y.; Iwasaki, T.; Abe, T.; Asamura, H.; et al. Infiltration of Tumor-associated Macrophages Is Involved in Tumor Programmed Death-ligand 1 Expression in Early Lung Adenocarcinoma. Cancer Sci. 2020, 111, 727-738. [CrossRef]

165. Xiong, H.; Mittman, S.; Rodriguez, R.; Moskalenko, M.; Pacheco-Sanchez, P.; Yang, Y.; Nickles, D.; Cubas, R. Anti-PD-L1 Treatment Results in Functional Remodeling of the Macrophage Compartment. Cancer Res. 2019, 79, 1493-1506. [CrossRef]

166. Viola, A.; Munari, F.; Sánchez-Rodríguez, R.; Scolaro, T.; Castegna, A. The Metabolic Signature of Macrophage Responses. Front. Immunol. 2019, 10, 1462. [CrossRef]

167. Palsson-McDermott, E.M.; Curtis, A.M.; Goel, G.; Lauterbach, M.A.R.; Sheedy, F.J; Gleeson, L.E.; van den Bosch, M.W.M.; Quinn, S.R.; Domingo-Fernandez, R.; Johnston, D.G.W.; et al. Pyruvate Kinase M2 Regulates Hif- $1 \alpha$ Activity and IL-1 $\beta$ Induction and Is a Critical Determinant of the Warburg Effect in LPS-Activated Macrophages. Cell Metab. 2015, 21, 65-80. [CrossRef]

168. Mazurek, S.; Boschek, C.B.; Hugo, F.; Eigenbrodt, E. Pyruvate Kinase Type M2 and Its Role in Tumor Growth and Spreading. Semin. Cancer Biol. 2005, 15, 300-308. [CrossRef]

169. Li, Y.; Zhang, P.; Wang, C.; Han, C.; Meng, J.; Liu, X.; Xu, S.; Li, N.; Wang, Q.; Shi, X.; et al. Immune Responsive Gene 1 (IRG1) Promotes Endotoxin Tolerance by Increasing A20 Expression in Macrophages through Reactive Oxygen Species. J. Biol. Chem. 2013, 288, 16225-16234. [CrossRef]

170. Van den Bossche, J.; Baardman, J.; Otto, N.A.; van der Velden, S.; Neele, A.E.; van den Berg, S.M.; Luque-Martin, R.; Chen, H.-J.; Boshuizen, M.C.S.; Ahmed, M.; et al. Mitochondrial Dysfunction Prevents Repolarization of Inflammatory Macrophages. Cell Rep. 2016, 17, 684-696. [CrossRef]

171. Wang, X.-F.; Wang, H.-S.; Wang, H.; Zhang, F.; Wang, K.-F.; Guo, Q.; Zhang, G.; Cai, S.-H.; Du, J. The Role of Indoleamine 2,3-Dioxygenase (IDO) in Immune Tolerance: Focus on Macrophage Polarization of THP-1 Cells. Cell Immunol. 2014, 289, 42-48 [CrossRef] [PubMed]

172. Cannon, M.J.; Ghosh, D.; Gujja, S. Signaling Circuits and Regulation of Immune Suppression by Ovarian Tumor-Associated Macrophages. Vaccines 2015, 3, 448-466. [CrossRef] [PubMed]

173. Haschemi, A.; Kosma, P.; Gille, L.; Evans, C.R.; Burant, C.F.; Starkl, P.; Knapp, B.; Haas, R.; Schmid, J.A.; Jandl, C.; et al. The Sedoheptulose Kinase CARKL Directs Macrophage Polarization through Control of Glucose Metabolism. Cell Metab. 2012, 15, 813-826. [CrossRef] [PubMed]

174. Palmieri, E.M.; Menga, A.; Martín-Pérez, R.; Quinto, A.; Riera-Domingo, C.; Tullio, G.D.; Hooper, D.C.; Lamers, W.H.; Ghesquière, B.; McVicar, D.W.; et al. Pharmacologic or Genetic Targeting of Glutamine Synthetase Skews Macrophages toward an M1-like Phenotype and Inhibits Tumor Metastasis. Cell Rep. 2017, 20, 1654-1666. [CrossRef] [PubMed]

175. Mantovani, A.; Sozzani, S.; Locati, M.; Allavena, P.; Sica, A. Macrophage Polarization: Tumor-Associated Macrophages as a Paradigm for Polarized M2 Mononuclear Phagocytes. Trends Immunol. 2002, 23, 549-555. [CrossRef]

176. Essandoh, K.; Li, Y.; Huo, J.; Fan, G.-C. MiRNA-Mediated Macrophage Polarization and Its Potential Role in the Regulation of Inflammatory Response. Shock 2016, 46, 122-131. [CrossRef] [PubMed]

177. Liu, G.; Abraham, E. MicroRNAs in Immune Response and Macrophage Polarization. Arterioscler. Thromb. Vasc. Biol. 2013, 33, 170-177. [CrossRef]

178. Yang, S.; Li, J.; Chen, Y.; Zhang, S.; Feng, C.; Hou, Z.; Cai, J.; Wang, Y.; Hui, R.; Lv, B.; et al. MicroRNA-216a Promotes M1 Macrophages Polarization and Atherosclerosis Progression by Activating Telomerase via the Smad3/NF-KB Pathway. Biochim. Biophysica Acta BBA Mol. Basis Dis. 2019, 1865, 1772-1781. [CrossRef]

179. ZHANG, Y.; ZHANG, M.; ZHONG, M.; SUO, Q.; LV, K. Expression Profiles of MiRNAs in Polarized Macrophages. Int. J. Mol. Med. 2013, 31, 797-802. [CrossRef]

180. Huang, C.; Liu, X.; Qun, Z.; Xie, J.; Ma, T.; Meng, X.; Li, J. MiR-146a Modulates Macrophage Polarization by Inhibiting Notch1 Pathway in RAW264.7 Macrophages. Int. Immunopharmacol. 2016, 32, 46-54. [CrossRef]

181. Dang, C.P.; Leelahavanichkul, A. Over-Expression of MiR-223 Induces M2 Macrophage through Glycolysis Alteration and Attenuates LPS-Induced Sepsis Mouse Model, the Cell-Based Therapy in Sepsis. PLoS ONE 2020, 15, e0236038. [CrossRef]

182. Karo-Atar, D.; Itan, M.; Pasmanik-Chor, M.; Munitz, A. MicroRNA Profiling Reveals Opposing Expression Patterns for MiR-511 in Alternatively and Classically Activated Macrophages. J. Asthma 2014, 52, 545-553. [CrossRef] 
183. Nywening, T.M.; Wang-Gillam, A.; Sanford, D.E.; Belt, B.A.; Panni, R.Z.; Cusworth, B.M.; Toriola, A.T.; Nieman, R.K.; Worley, L.A.; Yano, M.; et al. Targeting Tumour-Associated Macrophages with CCR2 Inhibition in Combination with FOLFIRINOX in Patients with Borderline Resectable and Locally Advanced Pancreatic Cancer: A Single-Centre, Open-Label, Dose-Finding, Non-Randomised, Phase 1b Trial. Lancet Oncol. 2016, 17, 651-662. [CrossRef]

184. Tacke, F. Cenicriviroc for the Treatment of Non-Alcoholic Steatohepatitis and Liver Fibrosis. Expert Opin. Investig. Drugs 2018, 27, 301-311. [CrossRef]

185. Yumimoto, K.; Sugiyama, S.; Mimori, K.; Nakayama, K.I. Potentials of C-C Motif Chemokine 2-C-C Chemokine Receptor Type 2 Blockers Including Propagermanium as Anticancer Agents. Cancer Sci. 2019, 110, 2090-2099. [CrossRef]

186. D'Incalci, M.; Badri, N.; Galmarini, C.M.; Allavena, P. Trabectedin, a Drug Acting on Both Cancer Cells and the Tumour Microenvironment. Br. J. Cancer 2014, 111, 646-650. [CrossRef]

187. Germano, G.; Frapolli, R.; Belgiovine, C.; Anselmo, A.; Pesce, S.; Liguori, M.; Erba, E.; Uboldi, S.; Zucchetti, M.; Pasqualini, F.; et al. Role of Macrophage Targeting in the Antitumor Activity of Trabectedin. Cancer Cell 2013, 23, 249-262. [CrossRef]

188. Guerriero, J.L.; Sotayo, A.; Ponichtera, H.E.; Castrillon, J.A.; Pourzia, A.L.; Schad, S.; Johnson, S.F.; Carrasco, R.D.; Lazo, S.; Bronson, R.T.; et al. Class IIa HDAC Inhibition Reduces Breast Tumours and Metastases through Anti-Tumour Macrophages. Nature 2017, 543, 428-432. [CrossRef]

189. Mannaerts, I.; Eysackers, N.; Onyema, O.O.; Beneden, K.V.; Valente, S.; Mai, A.; Odenthal, M.; van Grunsven, L.A. Class II HDAC Inhibition Hampers Hepatic Stellate Cell Activation by Induction of MicroRNA. PLoS ONE 2013, 8, e55786. [CrossRef]

190. Zeng, Y.; Li, B.; Liang, Y.; Reeves, P.M.; Qu, X.; Ran, C.; Liu, Q.; Callahan, M.V.; Sluder, A.E.; Gelfand, J.A.; et al. Dual Blockade of CXCL12-CXCR4 and PD-1-PD-L1 Pathways Prolongs Survival of Ovarian Tumor-Bearing Mice by Prevention of Immunosuppression in the Tumor Microenvironment. FASEB J. 2019, 33, 6596-6608. [CrossRef]

191. Zhang, W.; Zhu, X.-D.; Sun, H.-C.; Xiong, Y.-Q.; Zhuang, P.-Y.; Xu, H.-X.; Kong, L.-Q.; Wang, L.; Wu, W.-Z.; Tang, Z.-Y. Depletion of Tumor-Associated Macrophages Enhances the Effect of Sorafenib in Metastatic Liver Cancer Models by Antimetastatic and Antiangiogenic Effects. Clin. Cancer Res. 2010, 16, 3420-3430. [CrossRef]

192. Gladue, R.P.; Paradis, T.; Cole, S.H.; Donovan, C.; Nelson, R.; Alpert, R.; Gardner, J.; Natoli, E.; Elliott, E.; Shepard, R.; et al. The CD40 Agonist Antibody CP-870,893 Enhances Dendritic Cell and B-Cell Activity and Promotes Anti-Tumor Efficacy in SCID-Hu Mice. Cancer Immunol. Immunother. 2011, 60, 1009. [CrossRef]

193. Piechutta, M.; Berghoff, A.S. New Emerging Targets in Cancer Immunotherapy: The Role of Cluster of Differentiation 40 (CD40/TNFR5). ESMO Open 2019, 4, e000510. [CrossRef]

194. Ries, C.H.; Cannarile, M.A.; Hoves, S.; Benz, J.; Wartha, K.; Runza, V.; Rey-Giraud, F.; Pradel, L.P.; Feuerhake, F.; Klaman, I.; et al. Targeting Tumor-Associated Macrophages with Anti-CSF-1R Antibody Reveals a Strategy for Cancer Therapy. Cancer Cell 2014, 25, 846-859. [CrossRef]

195. Papadopoulos, K.P.; Gluck, L.; Martin, L.P.; Olszanski, A.J.; Tolcher, A.W.; Ngarmchamnanrith, G.; Rasmussen, E.; Amore, B.M.; Nagorsen, D.; Hill, J.S.; et al. First-in-Human Study of AMG 820, a Monoclonal Anti-Colony-Stimulating Factor 1 Receptor Antibody, in Patients with Advanced Solid Tumors. Clin. Cancer Res. 2017, 23, 5703-5710. [CrossRef] [PubMed]

196. Kaneda, M.M.; Messer, K.S.; Ralainirina, N.; Li, H.; Leem, C.J.; Gorjestani, S.; Woo, G.; Nguyen, A.V.; Figueiredo, C.C.; Foubert, P.; et al. PI3K $\gamma$ Is a Molecular Switch That Controls Immune Suppression. Nature 2016, 539, 437-442. [CrossRef]

197. Willingham, S.B.; Volkmer, J.-P.; Gentles, A.J.; Sahoo, D.; Dalerba, P.; Mitra, S.S.; Wang, J.; Contreras-Trujillo, H.; Martin, R.; Cohen, J.D.; et al. The CD47-Signal Regulatory Protein Alpha (SIRPa) Interaction Is a Therapeutic Target for Human Solid Tumors. Proc. Natl. Acad. Sci. USA 2012, 109, 6662-6667. [CrossRef] [PubMed]

198. Alvey, C.M.; Spinler, K.R.; Irianto, J.; Pfeifer, C.R.; Hayes, B.; Xia, Y.; Cho, S.; Dingal, P.C.P.D.; Hsu, J.; Smith, L.; et al. SIRPAInhibited, Marrow-Derived Macrophages Engorge, Accumulate, and Differentiate in Antibody-Targeted Regression of Solid Tumors. Curr. Biol. 2017, 27, 2065-2077. [CrossRef] [PubMed]

199. Viitala, M.K.; Virtakoivu, R.; Tadayon, S.; Rannikko, J.; Jalkanen, S.; Hollmén, M. Immunotherapeutic Blockade of Macrophage Clever-1 Reactivates the CD8+ T Cell Response Against Immunosuppressive Tumors. Clin. Cancer Res. 2019, 25, $3289-3303$. [CrossRef]

200. Gordon, S.R.; Maute, R.L.; Dulken, B.W.; Hutter, G.; George, B.M.; McCracken, M.N.; Gupta, R.; Tsai, J.M.; Sinha, R.; Corey, D.; et al. PD-1 Expression by Tumour-Associated Macrophages Inhibits Phagocytosis and Tumour Immunity. Nature 2017, 545, 495-499. [CrossRef]

201. Feng, Y.; Mu, R.; Wang, Z.; Xing, P.; Zhang, J.; Dong, L.; Wang, C. A Toll-like Receptor Agonist Mimicking Microbial Signal to Generate Tumor-Suppressive Macrophages. Nat. Commun. 2019, 10, 2272. [CrossRef]

202. Anand, S.; Majeti, B.K.; Acevedo, L.M.; Murphy, E.A.; Mukthavaram, R.; Scheppke, L.; Huang, M.; Shields, D.J.; Lindquist, J.N.; Lapinski, P.E.; et al. MicroRNA-132-Mediated Loss of P120RasGAP Activates the Endothelium to Facilitate Pathological Angiogenesis. Nat. Med. 2010, 16, 909-914. [CrossRef]

203. Baker, D.W.; Zhou, J.; Tsai, Y.-T.; Patty, K.M.; Weng, H.; Tang, E.N.; Nair, A.; Hu, W.-J.; Tang, L. Development of Optical Probes for in Vivo Imaging of Polarized Macrophages during Foreign Body Reactions. Acta Biomater. 2014, 10, 2945-2955. [CrossRef]

204. Jager, N.A.; Westra, J.; Golestani, R.; van Dam, G.M.; Low, P.S.; Tio, R.A.; Slart, R.H.J.A.; Boersma, H.H.; Bijl, M.; Zeebregts, C.J. Folate Receptor- $\beta$ Imaging Using $99 \mathrm{mTc}$-Folate to Explore Distribution of Polarized Macrophage Populations in Human Atherosclerotic Plaque. J. Nucl. Med. 2014, 55, 1945-1951. [CrossRef] 
205. Zhou, J.; Tsai, Y.-T.; Weng, H.; Baker, D.W.; Tang, L. Real Time Monitoring of Biomaterial-Mediated Inflammatory Responses via Macrophage-Targeting NIR Nanoprobes. Biomaterials 2011, 32, 9383-9390. [CrossRef]

206. Sun, J.Y.; Shen, J.; Thibodeaux, J.; Huang, G.; Wang, Y.; Gao, J.; Low, P.S.; Dimitrov, D.S.; Sumer, B.D. In Vivo Optical Imaging of Folate Receptor- $\beta$ in Head and Neck Squamous Cell Carcinoma. Laryngoscope 2014, 124, E312-E319. [CrossRef]

207. Sun, X.; Guo, L.; Shang, M.; Shi, D.; Liang, P.; Jing, X.; Meng, D.; Liu, X.; Zhou, X.; Zhao, Y.; et al. Ultrasound Mediated Destruction of LMW-HA-Loaded and Folate-Conjugated Nanobubble for TAM Targeting and Reeducation. Int. J. Nanomed. 2020, 15, 1967-1981. [CrossRef]

208. Movahedi, K.; Schoonooghe, S.; Laoui, D.; Houbracken, I.; Waelput, W.; Breckpot, K.; Bouwens, L.; Lahoutte, T.; Baetselier, P.D.; Raes, G.; et al. Nanobody-Based Targeting of the Macrophage Mannose Receptor for Effective In Vivo Imaging of TumorAssociated Macrophages. Cancer Res. 2012, 72, 4165-4177. [CrossRef]

209. Bathula, N.V.; Bommadevara, H.; Hayes, J.M. Nanobodies: The Future of Antibody-Based Immune Therapeutics. Cancer Biother. Radiopharm 2020. [CrossRef]

210. Keliher, E.J.; Yoo, J.; Nahrendorf, M.; Lewis, J.S.; Marinelli, B.; Newton, A.; Pittet, M.J.; Weissleder, R. 89 Zr-Labeled Dextran Nanoparticles Allow in Vivo Macrophage Imaging. Bioconjug. Chem. 2011, 22, 2383-2389. [CrossRef]

211. Berr, L.W.; Mayo, M.W.; Yoo, A.D.; Williams, M.B.; Berr, S.S. PET Imaging of Tumor Associated Macrophages Using Mannose Coated 64Cu Liposomes. Biomaterials 2012, 33, 7785-7793. [CrossRef]

212. Rodell, C.B.; Koch, P.D.; Weissleder, R. Screening for New Macrophage Therapeutics. Theranostics 2019, 9, 7714-7729. [CrossRef] [PubMed]

213. Miller, M.A.; Chandra, R.; Cuccarese, M.F.; Pfirschke, C.; Engblom, C.; Stapleton, S.; Adhikary, U.; Kohler, R.H.; Mohan, J.F.; Pittet, M.J.; et al. Radiation Therapy Primes Tumors for Nanotherapeutic Delivery via Macrophage-Mediated Vascular Bursts. Sci. Transl. Med. 2017, 9, eaal0225. [CrossRef] [PubMed]

214. Ng, T.S.C.; Garlin, M.A.; Weissleder, R.; Miller, M.A. Improving Nanotherapy Delivery and Action through Image-Guided Systems Pharmacology. Theranostics 2020, 10, 968-997. [CrossRef] [PubMed]

215. Pérez-Medina, C.; Tang, J.; Abdel-Atti, D.; Hogstad, B.; Merad, M.; Fisher, E.A.; Fayad, Z.A.; Lewis, J.S.; Mulder, W.J.M.; Reiner, T. PET Imaging of Tumor-Associated Macrophages with 89Zr-Labeled High-Density Lipoprotein Nanoparticles. J. Nucl. Med. 2015, 56, 1272-1277. [CrossRef] [PubMed]

216. Helfen, A.; Roth, J.; Ng, T.; Eisenblaetter, M. In Vivo Imaging of Pro- and Antitumoral Cellular Components of the Tumor Microenvironment. J. Nucl. Med. 2018, 59, 183-188. [CrossRef]

217. Helfen, A.; Schnepel, A.; Rieß, J.; Stölting, M.; Gerwing, M.; Masthoff, M.; Vogl, T.; Roth, J.; Höltke, C.; Wildgruber, M.; et al. S100A9-Imaging Enables Estimation of Early Therapy-Mediated Changes in the Inflammatory Tumor Microenvironment. Biomedicines 2021, 9, 29. [CrossRef]

218. Becker, A.; Hokamp, N.G.; Zenker, S.; Flores-Borja, F.; Barzcyk, K.; Varga, G.; Roth, J.; Geyer, C.; Heindel, W.; Bremer, C.; et al. Optical In Vivo Imaging of the Alarmin S100A9 in Tumor Lesions Allows for Estimation of the Individual Malignant Potential by Evaluation of Tumor-Host Cell Interaction. J. Nucl. Med. 2015, 56, 450-456. [CrossRef]

219. Eisenblaetter, M.; Flores-Borja, F.; Lee, J.J.; Wefers, C.; Smith, H.; Hueting, R.; Cooper, M.S.; Blower, P.J.; Patel, D.; Rodriguez-Justo, M.; et al. Visualization of Tumor-Immune Interaction-Target-Specific Imaging of S100A8/A9 Reveals Pre-Metastatic Niche Establishment. Theranostics 2017, 7, 2392-2401. [CrossRef]

220. Eisenblätter, M.; Ehrchen, J.; Varga, G.; Sunderkötter, C.; Heindel, W.; Roth, J.; Bremer, C.; Wall, A. In Vivo Optical Imaging of Cellular Inflammatory Response in Granuloma Formation Using Fluorescence-Labeled Macrophages. J. Nucl. Med. Off. Publ. Soc. Nucl. Med. 2009, 50, 1676-1682. [CrossRef]

221. Wildgruber, M.; Lee, H.; Chudnovskiy, A.; Yoon, T.-J.; Etzrodt, M.; Pittet, M.J.; Nahrendorf, M.; Croce, K.; Libby, P.; Weissleder, R.; et al. Monocyte Subset Dynamics in Human Atherosclerosis Can Be Profiled with Magnetic Nano-Sensors. PLoS ONE 2009, 4, e5663. [CrossRef] [PubMed]

222. Settles, M.; Etzrodt, M.; Kosanke, K.; Schiemann, M.; Zimmermann, A.; Meier, R.; Braren, R.; Huber, A.; Rummeny, E.J.; Weissleder, R.; et al. Different Capacity of Monocyte Subsets to Phagocytose Iron-Oxide Nanoparticles. PLoS ONE 2011, 6, e25197. [CrossRef]

223. Shih, Y.I.; Hsu, Y.; Duong, T.Q.; Lin, S.; Chow, K.N.; Chang, C. Longitudinal Study of Tumor-associated Macrophages during Tumor Expansion Using MRI. NMR Biomed. 2011, 24, 1353-1360. [CrossRef]

224. Leimgruber, A.; Berger, C.; Cortez-Retamozo, V.; Etzrodt, M.; Newton, A.P.; Waterman, P.; Figueiredo, J.L.; Kohler, R.H.; Elpek, N.; Mempel, T.R.; et al. Behavior of Endogenous Tumor-Associated Macrophages Assessed In Vivo Using a Functionalized Nanoparticle. Neoplasia 2009, 11, 459-468. [CrossRef]

225. Mukherjee, S.; Sonanini, D.; Maurer, A.; Daldrup-Link, H.E. The Yin and Yang of Imaging Tumor Associated Macrophages with PET and MRI. Theranostics 2019, 9, 7730-7748. [CrossRef] [PubMed]

226. Aghighi, M.; Theruvath, A.J.; Pareek, A.; Pisani, L.; Alford, R.; Muehe, A.M.; Sethi, T.K.; Holdsworth, S.J.; Hazard, F.K.; Gratzinger, D.; et al. Magnetic Resonance Imaging of Tumor Associated Macrophages: Clinical Translation. Clin. Cancer Res. 2018, 24. [CrossRef]

227. Zanganeh, S.; Hutter, G.; Spitler, R.; Lenkov, O.; Mahmoudi, M.; Shaw, A.; Pajarinen, J.S.; Nejadnik, H.; Goodman, S.; Moseley, M.; et al. Iron Oxide Nanoparticles Inhibit Tumour Growth by Inducing Pro-Inflammatory Macrophage Polarization in Tumour Tissues. Nat. Nanotechnol. 2016, 11, 986-994. [CrossRef] 
228. Masthoff, M.; Buchholz, R.; Beuker, A.; Wachsmuth, L.; Kraupner, A.; Albers, F.; Freppon, F.; Helfen, A.; Gerwing, M.; Höltke, C.; et al. Introducing Specificity to Iron Oxide Nanoparticle Imaging by Combining 57 Fe-Based MRI and Mass Spectrometry. Nano Lett. 2019, 19, 7908-7917. [CrossRef]

229. Niehoff, A.; Wachsmuth, L.; Schmid, F.; Sperling, M.; Faber, C.; Karst, U. Quantification of Manganese Enhanced Magnetic Resonance Imaging Based on Spatially Resolved Elemental Mass Spectrometry. ChemistrySelect 2016, 1, 264-266. [CrossRef]

230. Masthoff, M.; Gran, S.; Zhang, X.; Wachsmuth, L.; Bietenbeck, M.; Helfen, A.; Heindel, W.; Sorokin, L.; Roth, J.; Eisenblätter, M.; et al. Temporal Window for Detection of Inflammatory Disease Using Dynamic Cell Tracking with Time-Lapse MRI. Sci. Rep. 2018, 8, 9563. [CrossRef]

231. Melancon, M.P.; Lu, W.; Huang, Q.; Thapa, P.; Zhou, D.; Ng, C.; Li, C. Targeted Imaging of Tumor-Associated M2 Macrophages Using a Macromolecular Contrast Agent PG-Gd-NIR. Biomaterials 2010, 31, 6567-6573. [CrossRef] [PubMed]

232. Kim, H.-Y.; Li, R.; Ng, T.S.C.; Courties, G.; Rodell, C.B.; Prytyskach, M.; Kohler, R.H.; Pittet, M.J.; Nahrendorf, M.; Weissleder, R.; et al. Quantitative Imaging of Tumor-Associated Macrophages and Their Response to Therapy Using 64 Cu-Labeled Macrin. ACS Nano 2018, 12, 12015-12029. [CrossRef] [PubMed]

233. Martelli, C.; Dico, A.L.; Diceglie, C.; Lucignani, G.; Ottobrini, L. Optical Imaging Probes in Oncology. Oncotarget 2016, 7, 48753-48787. [CrossRef] [PubMed]

234. Yang, R.; Sarkar, S.; Yong, V.W.; Dunn, J.F. In Vivo MR Imaging of Tumor-Associated Macrophages: The Next Frontier in Cancer Imaging. Magn. Reson. Insights 2018, 11, 1178623X18771974. [CrossRef]

235. Terry, S.Y.A.; Boerman, O.C.; Gerrits, D.; Franssen, G.M.; Metselaar, J.M.; Lehmann, S.; Oyen, W.J.G.; Gerdes, C.A.; Abiraj, K. 111In-Anti-F4/80-A3-1 Antibody: A Novel Tracer to Image Macrophages. Eur. J. Nucl. Med. Mol. I 2015, 42, 1430-1438. [CrossRef]

236. Rashidian, M.; Keliher, E.J.; Bilate, A.M.; Duarte, J.N.; Wojtkiewicz, G.R.; Jacobsen, J.T.; Cragnolini, J.; Swee, L.K.; Victora, G.D.; Weissleder, R.; et al. Noninvasive Imaging of Immune Responses. Proc. Natl. Acad. Sci. USA 2015, 112, 6146-6151. [CrossRef]

237. Azad, A.K.; Rajaram, M.V.S.; Metz, W.L.; Cope, F.O.; Blue, M.S.; Vera, D.R.; Schlesinger, L.S. $\gamma$-Tilmanocept, a New Radiopharmaceutical Tracer for Cancer Sentinel Lymph Nodes, Binds to the Mannose Receptor (CD206). J. Immunol. 2015, 195, 2019-2029. [CrossRef]

238. Blykers, A.; Schoonooghe, S.; Xavier, C.; D’hoe, K.; Laoui, D.; D’Huyvetter, M.; Vaneycken, I.; Cleeren, F.; Bormans, G.; Heemskerk J.; et al. PET Imaging of Macrophage Mannose Receptor-Expressing Macrophages in Tumor Stroma Using 18F-Radiolabeled Camelid Single-Domain Antibody Fragments. J. Nucl. Med. 2015, 56, 1265-1271. [CrossRef]

239. Eichendorff, S.; Svendsen, P.; Bender, D.; Keiding, S.; Christensen, E.I.; Deleuran, B.; Moestrup, S.K. Biodistribution and PET Imaging of a Novel [68Ga]-Anti-CD163-Antibody Conjugate in Rats with Collagen-Induced Arthritis and in Controls. Mol. Imaging Biol. 2015, 17, 87-93. [CrossRef]

240. Unterrainer, M.; Mahler, C.; Vomacka, L.; Lindner, S.; Havla, J.; Brendel, M.; Böning, G.; Ertl-Wagner, B.; Kümpfel, T.; Milenkovic, V.M.; et al. TSPO PET with [18F]GE-180 Sensitively Detects Focal Neuroinflammation in Patients with Relapsing-Remitting Multiple Sclerosis. Eur. J. Nucl. Med. Mol. Imaging 2018, 45, 1423-1431. [CrossRef]

241. Vicidomini, C.; Panico, M.; Greco, A.; Gargiulo, S.; Coda, A.R.D.; Zannetti, A.; Gramanzini, M.; Roviello, G.N.; Quarantelli, M.; Alfano, B.; et al. In Vivo Imaging and Characterization of [18F]DPA-714, a Potential New TSPO Ligand, in Mouse Brain and Peripheral Tissues Using Small-Animal PET. Nucl. Med. Biol. 2015, 42, 309-316. [CrossRef]

242. Varnäs, K.; Cselényi, Z.; Jucaite, A.; Halldin, C.; Svenningsson, P.; Farde, L.; Varrone, A. PET Imaging of [11C]PBR28 in Parkinson's Disease Patients Does Not Indicate Increased Binding to TSPO despite Reduced Dopamine Transporter Binding. Eur. J. Nucl. Med. Mol. Imaging 2019, 46,367-375. [CrossRef]

243. Betzel, T.; Müller, C.; Groehn, V.; Müller, A.; Reber, J.; Fischer, C.R.; Krämer, S.D.; Schibli, R.; Ametamey, S.M. Radiosynthesis and Preclinical Evaluation of 3'-Aza-2'-[ 18 F]Fluorofolic Acid: A Novel PET Radiotracer for Folate Receptor Targeting. Bioconjug. Chem. 2013, 24, 205-214. [CrossRef]

244. He, H.; Chiu, A.C.; Kanada, M.; Schaar, B.T.; Krishnan, V.; Contag, C.H.; Dorigo, O. Imaging of Tumor-Associated Macrophages in a Transgenic Mouse Model of Orthotopic Ovarian Cancer. Mol. Imaging Biol. 2017, 19, 694-702. [CrossRef]

245. Choi, Y.J.; Oh, S.-G.; Singh, T.D.; Ha, J.-H.; Kim, D.W.; Lee, S.W.; Jeong, S.Y.; Ahn, B.-C.; Lee, J.; Jeon, Y.H. Visualization of the Biological Behavior of Tumor-Associated Macrophages in Living Mice with Colon Cancer Using Multimodal Optical Reporter Gene Imaging. Neoplasia 2016, 18, 133-141. [CrossRef]

246. Aalipour, A.; Chuang, H.-Y.; Murty, S.; D’Souza, A.L.; Park, S.; Gulati, G.S.; Patel, C.B.; Beinat, C.; Simonetta, F.; Martinić, I.; et al. Engineered Immune Cells as Highly Sensitive Cancer Diagnostics. Nat. Biotechnol. 2019, 37, 531-539. [CrossRef] 